\title{
CHANGES IN THE RELATIVE STRUCTURE OF WAGES AND EMPLOYMENT: A COMPARISON OF THE UNITED STATES, CANADA, AND FRANCE
}

\author{
David Card \\ Francis Kramarz \\ Thomas Lemieux
}

Working Paper 5487

\author{
NATIONAL BUREAU OF ECONOMIC RESEARCH \\ 1050 Massachusetts Avenue \\ Cambridge, MA 02138 \\ March 1996
}

Earlier drafts of this paper were presented at the January 1995 AEA Meetings and at the WennerGren Center conference "Unemployment and Wage Dispersion -- Is There a Trade-off?" in Stockholm, June 1995. We are grateful to Rebecca Blank, Stephen Nickell, and many seminar participants for comments and suggestions and to John Abowd and Dwayne Benjamin for help with the data. Special thanks to Alan Manning for many useful discussions. This paper is part of NBER's research program in Labor Studies. Any opinions expressed are those of the authors and not those of the National Bureau of Economic Research.

(C) 1996 by David Card, Francis Kramarz and Thomas Lemieux. All rights reserved. Short sections of text, not to exceed two paragraphs, may be quoted without explicit permission provided that full credit, including (c) notice, is given to the source. 


\title{
CHANGES IN THE RELATIVE STRUCTURE \\ OF WAGES AND EMPLOYMENT: A \\ COMPARISON OF THE UNITED STATES, \\ CANADA, AND FRANCE
}

\begin{abstract}
Standard models suggest that adverse labor demand shocks will lead to bigger employment losses if institutional factors like minimum wages and trade unions prevent downward wage adjustments. Some economists have argued that this insight explains the contrast between the United States, where real wages fell over the 1980s and aggregate employment expanded vigorously, and Europe, where real wages were (roughly) constant and employment was stagnant. We test this hypothesis by comparing changes in wages and employment rates over the 1980s for different age and education groups in the United States, Canada, and France. We argue that the same forces that led to falling real wages for less-skilled workers in the U.S. affected similar workers in Canada and France. Consistent with the view that labor market institutions are more rigid in France, and more flexible in the U.S., we find that relative wages of less-skilled workers fell the most in the U.S., fell somewhat less in Canada, and did not fall at all in France. Contrary to expectations, however, we find little evidence that wage inflexibilities generated divergent patterns of relative employment growth across the three countries.
\end{abstract}

David Card

Department of Economics

Princeton University

Princeton, NJ 08544

and NBER
Francis Kramarz

INSEE

92244 Malakoff Cedex

FRANCE
Thomas Lemieux Department of Economics University of Montreal PO Box 6128, Station A Montreal, PQ H3C 3J7

CANADA and NBER 
The U.S. labor market was characterized by three prominent trends during the 1980s: falling average real wages; widening wage inequality; and strong overall employment growth. The corresponding labor market trends in most Western Europe countries were very different. Average real wages increased or held steady. Indexes of wage inequality showed modest increases (in Britain) or no increase at all (in France and Germany, for example). Most noticeably, overall employment in many OECD countries was stagnant, implying massive increases in unemployment.

The contrast between the U.S. pattern of falling real wages and rising employment and the European pattern of rising real wages and stagnant employment has attracted wide attention. Some economists have speculated that employment growth in the United States has only been possible because of the flexibility that allowed real wages of less-skilled workers to decline in the face of persistent negative demand shocks. In Western Europe, on the other hand, institutional factors such as minimum wages, union wage setting, and generous unemployment benefits are thought to have prevented real wage declines among less-skilled workers and held down job growth. ${ }^{1}$

In this paper we attempt to evaluate the evidence in favor of this story. We use comparable data on employment and wage outcomes for workers in the United States, Canada, and France to study the relative changes in the structure of wages and employment that occurred in the three countries over the 1980s. The specific hypothesis that motivates our empirical analysis is quite simple. Suppose that similar negative shocks have affected the demand for lessskilled workers in all three countries. In the United States, where labor markets are relatıvely flexible, we would expect these shocks to result primarily in a decline in the relative wages of less-skilled workers. In France, where labor markets are relatively inflexible, we would expect these shocks to result primarily in a decline in the relative employment of less-skilled workers. Finally, in Canada, where labor market institutions lie somewhere between those of the United

\footnotetext{
${ }^{1}$ See Krugman (1993) for a clear statement of this view and Freeman (1994, page 14) and Katz, Loveman, and Blanchflower (1993, page 28) for more guarded statements.
} 
States and France, we would expect to see smaller relative wage changes than in the United States, and smaller relative employment changes than in France.

A key ingredient of our analysis is an index of the relative demand shocks that affected different skill groups in the three countries over the 1980s. We consider two alternatives. The first builds on the observation that wages of more highly-paid workers in the United States tended to rise more quickly (or fall more slowly) during the 1980s, regardless of the source of the pay differential -- higher education, greater labor market experience, or other factors. This pattern suggests that the level of wages for a particular skill group in the late 1970s or early 1980s can serve as a proxy for the relative demand shocks faced by group over the following decade. The second index of relative demand is linked to a more specific explanation for widening wage inequality: skill-biased technical change driven by innovations in computer technology. ${ }^{2}$ For each country we estimate the fraction of a particular skill group that used a computer on the job in the late 1980s, and interpret this fraction as an index of the relative demand for the group.

In our empirical analysis we compare the changes in wages and employment rates for different age and education groups in the three countries over the 1980s, and correlate these changes with the relative demand indexes. For the United States, we find that groups with lower wages at the beginning of the $1980 \mathrm{~s}$-- or lower rates of computer use at the end of the 1980s - had significantly slower wage and employment growth over the decade. The conventional interpretation of these patterns is that negative demand shocks led to downward pressure on the real wages of less-skilled workers, causing reductions in labor supply (e.g. Juhn (1992)). Our U.S. estimates imply elasticities of labor supply (or more precisely, employment participation) in the range of 0.2 to 0.4 .

The patterns of relative wage growth in Canada are similar to those in the U.S., although the magnitudes of the wage changes between groups are smaller in Canada, especially for women. Surprisingly, however, the patterns of relative employment growth in Canada closely

\footnotetext{
${ }^{2}$ See Krueger (1993) and Berman, Bound, and Griliches (1994) for example.
} 
parallel those in the U.S. There is no evidence that relative wage inflexibility led to larger swings in relative employment for less-skilled workers in Canada than in the U.S.

Our results for France present an even bigger puzzle. Consistent with the view that French labor market institutions restrict relative wage flexibility, we find that wage differentials between skill groups held constant or narrowed slightly over the 1980s. As in Canada, however, we find little evidence that this apparent rigidity in relative wages translated into greater employment losses for less-skilled workers. Indeed, the pattern of employment-population growth rates across age-education cells in France is almost identical to the pattern in the United States. Taking the evidence for the United States, Canada, and France as a whole, we conclude that it is very difficult to maintain the hypothesis that the "wage inflexibility" in Canada and France translated into greater relative employment losses for less-skilled workers in these countries. $^{3}$

\section{An Overview of Labor Markets in the United States. Canada, and France}

\section{A. Macro Trends}

Figure 1 presents a variety of information on aggregate labor market trends in the United States, Canada, and France over the past three decades. Panel A of the Figure shows total civilian employment in the three countries, indexed to a 1979 base. The graph illustrates two important points. First, overall employment grew by about 20 percent in Canada and the United States over the 1980s, compared with only about 3 percent growth in France. Second, slow employment growth in France over the 1980s was largely a continuation of earlier trends. Between 1966 and 1979, for example, employment in France grew by only 10 percent, compared with 40 percent increases during the same period in Canada and the United States. In part, slower employment growth in France reflects slower population growth. As shown in Panel B of Figure 1, however, when employment is measured relative to the adult population, the

\footnotetext{
${ }^{3} \mathrm{~A}$ similar conclusion is reached by Nickell and Bell (1995).
} 
divergence in long-run trends between the two North American economies and France remains. The employment-population rate grew by 3-4 percentage points in the United States and Canada between 1979 and 1989 and declined by 3 percentage points in France.

Given the divergent employment trends in panel A, the similarity of trends in real output for the three countries in Panel C is potentially surprising. Real GDP grew at an annual rate of about 2.5 percent per year over the 1980s in both the United States and Canada, and at only a slightly slower annual rate (about 2.2 percent per year) in France. ${ }^{4}$ As a result of the relatively similar growth rates in total output in the three countries, and the much slower growth rate of employment in France, labor productivity (as measured by GDP per employed worker) grew more rapidly in France than in Canada or the United States (Panel D).

Figure 2 graphs indexes of real hourly wage rates for the three economies over the 196691 period. These indexes pertain to gross hourly wages in manufacturing (excluding fringe benefits or employer tax contributions), and are deflated with country-specific consumer price indexes to a 1979 base. ${ }^{5}$ Using this definition of earnings, average real wages in the United States declined in the 1980 s by 10 percent, while real wages in Canada declined slightly ( 3 percent) and those in France rose by about 10 percent. Other wage series tend to show similar relative patterns of real wage changes across the three countries, although the precise magnitudes differ by data source, earnings concept, price deflator, and sector.

To summarize, aggregate labor market data from the United States, Canada, and France show that the U.S. and Canada had strong employment growth over the 1980s, while employment was roughly constant in France. On the other hand, real wages increased in France over the decade, while they fell in the United States, and were roughly constant in Canada.

\footnotetext{
${ }^{4}$ These estimates are derived from trend models fit to log real GDP of the three countries. The models assume a constant trend in the United States, and trend shifts in Canada and France in 1979 and 1974, respectively.

${ }^{5}$ The data for Figure 2 represent wage rates collected from employer surveys in the three countries, and are taken from OECD Main Economic Indicators 1991 edition.
} 


\section{B. Sources of Relative Labor Demand Shocks}

There is now a well-established literature on the sources of widening wage inequality within the U.S. labor market -- see e.g. Murphy and Welch (1991), Bound and Johnson (1992), Katz and Murphy (1992), Borjas and Ramey (1993a, 1994), Lawrence and Slaughter (1993), and Kosters (1994). A primary conclusion from this literature is that the decline in relative wages of less-skilled workers during the 1980s was driven by relative shifts in labor demand. The two leading explanations for these shifts are skill-biased technical change and trade.

With respect to technological change, many analysts have pointed to computer technology as a factor that tends to raise the relative productivity of more highly-skilled workers, leading to a decline in the demand for less-skilled labor (see Bound and Johnson (1992) and Krueger (1993)). With respect to trade, standard theory suggest that the opening-up of trade will lower the demand for workers in industries that must compete with the newly-available import goods. If younger or less-educated workers are disproportionately employed in trade-impacted industries, rising trade may raise skill premiums throughout the labor force. ${ }^{6}$

To what extent have the same kinds of technology and trade shocks affected labor markets in France and Canada? To get a rough impression we assembled data on computer usage and trade flows in Tables 1 and 2. Table 1 shows the fraction of the workforce who report that they use a computer at work as of the late 1980s in the United States, Canada, and France. We present the overall fractions of workers who use computers, and usage rates by gender and education. Overall usage rates are marginally higher in the U.S. than in Canada or France, but the diffusion of computer technology has proceeded at a fairly similar pace in the three economies. Women in each country are more likely to use a computer at work then men, perhaps reflecting occupational differences in the diffusion of computer technology.

\footnotetext{
${ }^{6}$ The empirical plausibility of the case that trade has affected relative wages is a matter of some dispute. See Bhagwati and Dehejia (1994), Lawrence (1994), and Leamer (1994) for example.
} 
As shown in row 3 of Table 1, better-educated workers are also more likely to use a computer, and in fact usage rates for college graduates are fairly similar in the three countries. For those without a college degree computer usage rates are 30-45 percent higher in Canada and France than in the United States. Conditional on education, computer use is therefore lower in the U.S. than in Canada or France. Of course it might be argued that the actual "human capital" embodied in lower education categories in Canada or France is higher than in the comparable U.S. categories, making it difficult to compare usage rates conditional on education across countries.

Turning to the issue of trade, Table 2 presents a series of import penetration ratios for the three countries in 1973,1983, and 1993. The first column of the table shows the ratio of total imports to GDP in each country. Compared to Canada or France (or indeed, to most other OECD nations), the United States is a low-trade country. Nevertheless, the rate of growth of imports relative to domestic output was slightly faster in the United States than in France or Canada over the past two decades. Interestingly, however, U.S. imports expanded more rapidly during the 1970s than the 1980s. Concentrating only on the 1980s, imports grew more slowly in the United States than in the other two countries.

One could argue that even though the United States is a low-trade country, it is more vulnerable to import competition from low-wage countries, or from countries with technological advantages in certain products (like Japan). To address this issue, we re-calculated the importpenetration ratios, excluding Canadian imports from the U.S. data, U.S. imports from the Canadian data, and European imports from the French data. The results, presented in the third column of Table 2, show that even under this highly restrictive notion of import penetration, the rates of growth of imports in the three countries are roughly comparable. On balance, we

\footnotetext{
${ }^{7}$ This conclusion continues to hold when we use 1969, 1979, and 1989 data.

${ }^{8}$ Since trade between the U.S. and Canada is relatively unrestricted and many firms operate on both sides of the border, one might argue that Canada is vulnerable to the same shocks that affect the U.S. labor market.
} 
believe there is a reasonable case that increasing trade has had at least as large an impact on labor demand in Canada and France as in the United States.

\section{What About Supply?}

While research on the changing structure of wages in the United States has generally concluded that labor demand shocks are the cause of rising wage inequality, some comparative studies (Katz, Loveman, and Blanchflower (1993), Freeman and Needels (1994)) have argued that relative supply changes have tended to mitigate these shocks in France, Canada, and other countries. This argument is most often raised with respect to the supply of new college graduates, which, it is argued, expanded more rapidly in other countries than in the United States over the 1980s. In the empirical analysis that follows we control for relative changes in supply in a manner suggested by a simple supply-demand model. Nevertheless, it may be useful to provide an overview of the major trends in the relative supply of labor by skill group in the three countries.

Table 3 presents two types of data on the relative supplies of highly-skilled labor. Row 1 of the table contains estimates of the fraction of the adult population that was "highly educatod" at the beginning of the 1980s. ${ }^{9}$ We define highly educated people as those with 16 or more years of schooling in the United States, those with a university degree in Canada, and those who have completed Etudes Superieures in France. In early 1980s the fraction of men with a university degree in the U.S. was approximately twice as high as in Canada or France. The relative differences were slightly smaller for women. ${ }^{10}$ The second row of the table gives the change in the fraction of highly educated individuals in the adult population of each country over the 1980s, while the third row gives the percentage change in the highly-educated population

${ }^{9}$ See Appendix 1 for more information on the samples in this table.

${ }^{10}$ Note that the entries in Table 3 are for the adult population rather than for workers. Among working women the fractions with a college degree are higher than shown in the Table. 
share. In percentage terms the fraction of men with a college-level education rose slightly faster in France than in the U.S. or Canada. Among women, the percentage rise was fastest in Canada and slowest in France.

Another way to compare the changes in the relative supplies of skilled labor in the three countries is to compute an index like

(1) $\quad \Sigma_{j} s_{j}\left(f_{j t}-f_{j t-1}\right)$,

where $\mathbf{j}$ indexes different skill groups (e.g., distinct age-education cells), $\mathbf{f}_{\mathbf{j t}}$ is the fraction of the adult population in skill group $j$ in year $t$, and $s_{j}$ is a measure of the relative skill of group $j$. A simple choice for $\mathrm{s}_{\mathrm{j}}$ is the mean wage (or mean log wage) of workers in skill group $\mathrm{j}$ in either the base period or the ending period of the comparison. In this case, equation (1) has the interpretation of the change in mean wages (or mean log wages) between periods $\mathrm{t}-1$ and $\mathrm{t}$ that is attributable to the changing distribution of the population across skill groups. Note that if the skill groups are stratified by age and education, then an expression like (1) accounts in a relatively simple way for changes in both the relative supply of different education groups, and the relative supply of different age groups.

We computed equation (1) by gender for the three countries using a total of 225 distinct age-education cells for the United States, 70 cells for France, and 29 cells for Canada." We calculated the skill change index using two alternative choices for weights: the mean log wage of the group at the start of the 1980s, and the mean log wage at the end of the 1980s.

As shown in rows 4 and 5 of Table 3, the resulting skill-change indexes indicate that the relative supply of more highly-skilled workers increased in all three countries. For men, the indexes suggest that the relative supply of highly-skilled labor increased most rapidly in the United States, while for women the increases were fairly similar in the three countries. These

${ }^{11}$ Since the available sample sizes are smaller in France than in the United States, a smaller number of cells is used to keep the average cell size large enough. The smaller number of cells for Canada is necessitated by the fact that age and education are coded into relatively few categories in the Canadian data sets. See Appendix 1 for more discussion of the cell definitions. 
comparisons must be interpreted carefully, because wage differentials across groups tend to be larger in the United States than other countries, so that a given shift in the population across ageeducation cells would be expected to generate a larger change in average wages in the United States. Nevertheless, the data suggest to us that relative supply shifts were not too dissimilar in the three countries during the 1980 s. $^{12}$

\section{Sources of Labor Market Inflexibility}

A maintained assumption throughout this paper is that institutional forces that bolster the real wages of lower-paid workers are less important in the United States than in Canada or France. In this section we briefly summarize some descriptive evidence consistent with this hypothesis. We emphasize that our concern is with policies and programs that prevent the relative decline of wages for workers near the bottom of the wage distribution, rather than with more general notions of wage flexibility.

Among the most prominent institutional features of modern labor markets that may contribute to relative wage inflexibility are minimum wage laws, collective bargaining agreements, and income support programs for unemployed, disabled, or retired workers. Other factors that may also contribute to wage inflexibility include public ownership or regulation of firms (on the assumption that publicly-owned or regulated firms may face political pressures to maintain relative wage structures), and laws that limit or penalize layoffs (and thereby discourage mobility of labor across firms or sectors).

\footnotetext{
${ }^{12} \mathrm{~A}$ final aspect of the supply side of the labor market that may be relevant for a comparison between the three countries is immigration. Although Canada and France had a higher fraction of foreign born residents than the United States in the mid-1970s, the United States had a higher net immigration rate over the $1980 \mathrm{~s}$. Our analysis of relative supplies by age-education categories captures some part of effect of immigration, but may understate the contribution of immigrant flows to the relative supply of less-skilled workers, if immigrants are actually less skilled than natives with the same observable age and education characteristics.
} 
The United States, Canada, and France all have minimum wage regulations. ${ }^{13}$ A conventional measure of the impact of minimum wage laws is the ratio of the minimum wage to the average wage of workers in the labor market. Figure 3 plots this ratio for the three countries over the 1966-93 period. ${ }^{14}$ The figure shows that relative minimum wages in Canada and the United States fell sharply from the late 1970s to the late 1980s, with modest rebounds in both countries in the early 1990s. In France, by comparison, minimum wages edged up slightly relative to average salaries in the early 1980s, and then remained constant. The decline in the relative value of the minimum wage in the United States and Canada over the 1980s suggests that minimum wage regulations probably did not prevent relative wage declines for less-skilled workers in either country. On the other hand, the continuing high level of the relative minimum wage in France suggests that the minimum wage could have played an important role in reducing relative wage flexibility in the French labor market (see Katz, Loveman, and Blanchflower, 1993).

Table 4 presents comparative information on the extent of union membership and collective bargaining coverage in the three countries. In Canada and the United States, collective bargaining coverage is determined at the establishment level. Since about 90 percent of workers who are covered by union contracts in both countries are union members, it is customary to use

${ }^{13}$ For an overview of U.S. minimum wage laws, see Card and Krueger (1995). For a discussion of Canadian laws, see West and McKee (1980) and Baker, Benjamin, and Stanger (1994). For a discussion of the French minimum wage (the salaire minimum interprofessionnel de croissance, or SMIC) see Bayet (1994).

${ }^{14}$ For the United States, we divide the federal minimum wage by the average hourly wage in manufacturing. For Canada, we use a weighted average of province-specific ratios of the minimum wage to average hourly wage of manufacturing workers. We are grateful to Dwayne Benjamin for supplying his data for this calculation. For France, we use the ratio of the average annual SMIC (net of the employee share of the payroll tax), multiplied by an estimate of average hours per year (for full time full year workers) and divided by an estimate of average net annual salaries. See Bayet (1994). 
union membership rates as a measure of the extent of collective bargaining coverage. ${ }^{15}$ The data in the first two columns of Table 4 show that although unionization rates were similar in the United States and Canada in the early 1970s, by 1980 the Canadian rate was 50 percent higher. Over the 1980s the divergence continued, with declining unionization in the United States and roughly steady rates in Canada.

Collective bargaining institutions in France (and other European countries) are quite different from those in North America. In France, collective bargaining at the industry level sets baseline pay scales that apply to most employees in the industry, while additional enterprise or establishment agreements cover about one-fifth of workers, mainly in larger companies. ${ }^{16}$ Within this setting, individual union membership has no direct effect on collective bargaining coverage. As shown in Table 4, union membership rates were declining in France throughout the 1970s and 1980s: recent data suggest that only 10 percent of workers are union members. Nevertheless, collective bargaining coverage remains very high (over 90 percent). This high coverage rate suggests that collective bargaining institutions may exert some effect on the structure of wages in France -- especially in preventing the decline in relative wages of the least skilled workers. ${ }^{17}$

A final set of institutions that play some role in determining the downward-flexibility of low-skilled workers' wages are unemployment insurance and income support programs. These programs differ across the three countries in their generosity and even more importantly in their

${ }^{15}$ In both the United States and Canada, union membership rates and union coverage rales tend to show very similar cross-sectional patterns and trends. See Lemieux (1992) and Riddell (1992).

${ }^{16}$ See U.S. Department of Labor (1992).

${ }^{17}$ We have been unable to find any systematic data on the relative level of the industry minimum pay scales, or on the fraction of workers who are paid a wage at or close to the collectively-bargained wage floor that applies to their job. One source (INSEE, 1980) notes ..."le domaine des conventions collectives est un veritable 'maquis'..." According to another source (U.S. Department of Labor 1992), the failure to update industry agreements over the 1980 s led to cases where the industry wage scale fell below the national minimum wage, suggesting that the industry pay scales are not always binding. 
coverage. For example, France, Canada, and the United States all offer limited-duration unemployment benefits to workers who have lost a job and meet certain eligibility requirements. ${ }^{18}$ For those who receive such benefits, the programs typically "replace" about 60 percent of previous wages. In the U.S., however, the program provides benefits to a relatively small fraction of unemployed individuals. Moreover, the fraction of insured unemployed workers fell significantly during the 1980 s (from around 40 percent to under onethird -- see Blank and Card, 1991). By comparison, the Canadian unemployment insurance system is far more inclusive: during the 1980 s the Canadian program typically provided benefit payments to more people than were classified as unemployed (Card and Riddell (1993)). Estimates by the OECD suggest that French unemployment benefits are also relatively inclusive. In 1990, benefits were paid to about as many people as were counted as unemployed in the French labor force survey (OECD, 1994, Table 8.4).

The range of support programs available for non-workers in the three countries is also quite different. In the U.S., only Food Stamps are available to essentially all able-bodied nonworkers; traditional "welfare" payments are available only to single women with dependent children. ${ }^{19}$ By comparison, both Canada and France have social assistance programs that provide cash payments for nonworkers regardless of gender, disability status, or family structure.

Although it is difficult to make precise comparisons of the "safety net" programs in the three countries, there is little question that the U.S. has the least generous set of programs. A simple comparison between Canada and France is more difficult. A recent study by the OECD (1994) suggests that France has more generous unemployment-related programs than Canda (especially taking account of the long-term unemployed), and that the generosity of the French programs actually expanded over the 1980s, while those in Canada and the U.S. were more

\footnotetext{
${ }^{18}$ The U.S. and Canadian programs are similar in broad outline, while the French system includes a second stage of extended benefits for those who exhaust the first stage.

${ }^{19}$ Disability insurance payments are available to individuals whose physical or health conditions limit their ability to work.
} 
stable. Taken as a whole, we suspect that minimum wage laws, collective bargaining institutions, and social safety net programs are most likely to affect the degree of downward wage flexibility for less-skilled workers in France, and least likely to exert such an influence in the United States.

\section{Relative Wages and Employment Patterns}

\section{A. Theoretical Framework}

We now present a simple theoretical model that provides a convenient framework for interpreting relative changes in wages and employment rates of different skill groups and modelling the effect of relative wage rigidity on relative employment patterns. We concentrate on a model with a single industry because previous work (e.g. Bound and Johnson (1992), Katz and Murphy (1992)) has concluded that within-industry relative demand shocks have been the major source of declining wages for less-skilled workers in the United States, whereas betweenindustry factors have had only a secondary role. Consider a competitive economy in which firms use J different labor inputs $N_{1}, N_{2}, \ldots, N_{J}$ to produce a homogenous output $Y$. Suppose that output in period $t$ is related to the inputs by a constant-returns-to-scale CES production function:

$$
\begin{aligned}
Y_{\mathrm{t}} & =\mathrm{f}\left(\mathrm{N}_{\mathrm{lt}}, \mathrm{N}_{2 \mathrm{t}}, \ldots \mathrm{N}_{\mathrm{Jt}}\right), \\
& =\left\{\Sigma_{\mathrm{j}}\left(c_{\mathrm{jt}} \mathrm{N}_{\mathrm{j}}\right)^{(\sigma-1) / \sigma}\right\} \sigma /(\sigma-1)
\end{aligned}
$$

where $\sigma$ is the elasticity of substitution, and $c_{j t}$ is a relative efficiency parameter for skill-group $j$ in period $t^{20}$ If the wage rate for skill group $j$ is denoted by $w_{j t}$, then the demand for labor of the jth skill group in period $t$ is given by:

(3) $\log \mathrm{N}_{\mathrm{jt}}=\log \mathrm{Y}_{\mathrm{t}}-\sigma \log \mathrm{w}_{\mathrm{jt}}+(\sigma-1) \log \mathrm{c}_{\mathrm{jt}}$.

${ }^{20}$ Any "factor neutral" technical change results in a proportional shift in all the $c_{j t}$ 's. A model similar to the one here, but ignoring labor supply, is presented by Bound and Johnson (1992). 
Assuming that $\sigma>1$, a rise in $c_{\mathrm{jt}}$, the relative efficiency of group $\mathrm{j}$, leads to an increase in the demand for group $\mathrm{j}$, holding constant total output. As noted by Bound and Johnson (1992), there are several possible interpretations of the relative demand shift variable $c_{j t}$. One that we emphasize here is as a technological innovation that alters the relative efficiency of different groups of workers. Another (that we ignore) is as a shift in the human capital of individuals in the jth group, for example arising through changes in the quality of schooling.

Assume that the population in period $t$ contains $P_{j \mathrm{j}}$ individuals in the $\mathrm{jth}$ skill class, and that each individual from the jth group who chooses to work supplies a fixed number of hours per period (normalized to 1). Finally, assume that individuals within each skill group differ in their reservation wages, and that when the (real) wage rate is $w_{j t}$ a fraction $p_{j t}$ choose to work, where

(4) $\mathrm{p}_{\mathrm{jt}}=\mathrm{N}_{\mathrm{jl}} / \mathrm{P}_{\mathrm{jt}}=\mathrm{w}_{\mathrm{jt}}^{\mathrm{e}}$.

The parameter $\epsilon$ represents the elasticity of labor supply: for simplicity, we assume that $\epsilon$ is constant across groups. Let $P_{t}$ represent the total (adult) population in period $t$, let $y_{t}=Y_{t} / P_{t}$ represent per capita output in period $t$, and let $f_{j t}=P_{j t} / P_{t}$ represent the fraction of the population in skill group j. Making use of these definitions, equations (3) and (4) can be combined to yield simple expressions for the real wage rate and employment-population rate of group $\mathrm{j}$ in period t:

(5a) $\log w_{j t}=\frac{1}{\sigma+\epsilon}\left\{\log y_{t}+(\sigma-1) \log c_{j t}-\log f_{j t}\right\}$

(5b) $\log \mathrm{p}_{\mathrm{jt}}=\frac{\epsilon}{\sigma+\epsilon}\left\{\log \mathrm{y}_{\mathrm{t}}+(\sigma-1) \log \mathrm{c}_{\mathrm{jt}}-\log \mathrm{f}_{\mathrm{jt}}\right\}$.

These equations relate group-specific wages and employment-population rates to a year-specific productivity term $\left(\log y_{v}\right)$, and the relative demand and supply shocks $c_{j t}$ and $f_{j t}$.

If data are available for two different periods, then this simple model implies that the observed changes in group-specific wages and employment-population rates will be given by: 
(6a) $\Delta \log w_{j}=b_{1}+\frac{1}{\sigma+\epsilon}\left\{(\sigma-1) \Delta \log c_{j t}-\Delta \log f_{j t}\right\}$,

(6b) $\Delta \log \mathrm{p}_{\mathrm{j}}=\mathrm{b}_{2}+\frac{\epsilon}{\sigma+\epsilon}\left\{(\sigma-1) \Delta \log \mathrm{c}_{\mathrm{jt}}-\Delta \log \mathrm{f}_{\mathrm{jt}}\right\}$,

where $b_{1}$ and $b_{2}$ are constants. Note that, given any particular definition of skill groups, $f_{j t}$ is observable from conventional labor market survey data. A more difficult task is to derive observable proxies for the relative demand shifts. ${ }^{21}$

Our measures of the relative demand shocks are motivated by two recent findings in the wage inequality literature. One is that groups with higher wages had faster wage growth over the $1980 \mathrm{~s}^{22}$ This suggests that the level of wages of the jth group at some point prior to the $1980 s\left(\log w_{j 0}\right)$ is a good predictor of relative demand shock faced by the group over the decade (although the precise cause of the demand shift is not explained). A second finding is that bettereducated workers are more likely to use a computer at work (see Table 1), and that differential patterns of computer use can account for part of the rise in the return to education in the U.S. over the 1980s (Krueger (1993)). This and other evidence have led some analysts to conclude that personal computers represent a skill-biased technical innovation. ${ }^{23}$ In the spirit of this conclusion, our second demand shift index is simply the fraction of the jth skill group who are observed using computers at work at some time in the late $1980 \mathrm{~s}\left(\mathrm{cu}_{\mathrm{j}}\right)$. Let dem $\mathrm{j}_{\mathrm{j}}$ represent the variable used $\left(\mathrm{cu}_{\mathrm{ja}}\right.$ or $\left.\log \mathrm{w}_{\mathrm{j} 0}\right)$ to predict the relative demand shock experienced by group $\mathrm{j}$ :

(7) $(\sigma-1) \Delta \log c_{j t}=\alpha+\beta \operatorname{dem}_{j}+u_{j}$,

where $\beta<0$. Substitution of (7) into (6a) and (6b) leads to estimable equations of the form:

${ }^{21}$ The demand shift indexes used in studies like Katz and Murphy (1992) and Bound and Johnson (1992) capture changes attributable to differential demand shifts across industries. Our single industry model ignores these shifts.

${ }^{22}$ This fact is dramatically illustrated by the percentile plots presented by Juhn, Murphy, and Pierce (1993), which show a steady fanning out of the percentiles of wages over the 1980s. See Card and Lemieux (1995) for an attempt to test "one-factor" models of the structure of wages.

${ }^{23}$ See Berman, Bound, and Griliches (1994) and Bound and Johnson (1992). 
(8a) $\Delta \log w_{j}=d_{1}+\frac{\beta}{\sigma+\epsilon} \operatorname{dem}_{j}-\frac{1}{\sigma+\epsilon} \Delta \log \mathrm{f}_{\mathrm{jt}}+\mathrm{e}_{\mathrm{jl}}$,

and

(8b) $\Delta \log \mathrm{p}_{\mathrm{j}}=\mathrm{d}_{2}+\frac{\beta \epsilon}{\sigma+\epsilon} \mathrm{dem}_{\mathrm{j}}-\frac{\epsilon}{\sigma+\epsilon} \Delta \log \mathrm{f}_{\mathrm{jt}}+\mathrm{e}_{\mathrm{j} 2}$,

where $d_{1}$ and $d_{2}$ are constants, and $e_{j 1}$ and $e_{j 2}$ are stochastic terms representing a combination of the error term in the prediction equation for relative demand shifts $\left(u_{j}\right)$ and any sampling errors in the observed data on wages and employment rates. Notice that this model is over-identified, since only 3 underlying parameters determine the four partial regression coefficients relating changes in wages and employment rates to the demand shock and the change in the population share.

The assumptions underlying the derivation of equations (6a) and (6b) are highly restrictive. A particularly strong assumption is that there is a single elasticity of substitution between all pairs of skill groups. More realistically, one might conjecture that workers in one skill group are better substitutes for workers with "nearly the same" characteristics. In principle, a full set of cross-elasticities of factor demand for each skill group can be introduced, but the number of parameters becomes unmanageable in the absence of some very restrictive assumptions about substitutability.

A second assumption is that workers within each skill group are equally productive and differ only in their reservation wages. This assumption implies that the mean wage for workers in a given skill group is an unbiased estimate of the wage that would be observed for the nonworkers in the group if they chose to work. A (possibly) more realistic assumption is that workers in each group are perfect substitutes in production, but that different individuals in the group have different relative productivities. In this case, the potential wage of the ith person in the $\mathrm{jth}$ group in period $\mathrm{t}$ can be written as

$$
\log w_{i j t}=\log w_{j t}+k_{i j}
$$


where $w_{j t}$ is the wage for a "standardized" person in group $j$ (e.g., the person with the median productivity level). This assumption introduces two complications into the simple model of equations (6a) and (6b). First, the "effective" labor force of the jth skill group is no longer a simple head count, but must be adjusted for the relative productivities of those who are actually observed working. A second and related issue is that the observed wage of the group may vary as the employment rate varies, depending on the relative productivities of workers and nonworkers in the group. ${ }^{24}$

There are a number of ways to control for changes in the observed wages of a particular skill group that are attributable to changes in the composition of employment within the group. rather than to changes in underlying supply or demand factors. One simple method that we use in the next section is to assume that nonworkers would earn a relatively low wage -- specifically the minimum wage for the period of observation -- and recalculate the mean wage changes accordingly. An alternative (examined in Appendix 2) is to use the median wage (or some other percentile), assuming that non-workers in the skill group would be paid less than the median wage for the group.

\section{B. Effect of Downward Wage Rigidity}

Equations (6a) and (6b) are derived under the assumption that wages can freely adjuse to their equilibrium levels following a relative demand shock. What happens if wages can only partially adjust? To illustrate this case, denote the "optimal" wage change given by equation ( $\mathrm{ha}$ ) as $\Delta \log w_{j}^{*}$, and suppose that $\Delta \log w_{j}^{*}<0$. Assume that institutional rigidities or wher constraints lead to an actual wage change of the amount:

$$
\Delta \log w_{j}=\delta+\lambda \Delta \log w_{j}^{*},
$$

${ }^{24}$ From the point of view of modelling the mean log wage of the group, this is a standard sample selection problem. If labor supply within the group is systematically related to relative productivities, then the observed mean wage will be a biased estimate of the wage for a randomly selected member of the group. 
where $\delta$ is a constant and $0<\lambda \leq 1$ represents a flexibility parameter. A value of $\lambda=1$ corresponds to complete relative wage flexibility, whereas a value of $\lambda=0$ corresponds to complete downward wage rigidity.

If wages only partially adjust to their equilibrium values, then employment will be determined by the demand curve, rather than by the intersection of supply and demand. ${ }^{25}$ Assuming that the relative demand shocks are related to initial wages by equation (7) and that the initial wage is in equilibrium, equations (8a) and (8b) will be replaced by:

(9a) $\Delta \log w_{j}=d_{3}+\frac{\lambda \beta}{\sigma+\epsilon} \operatorname{dem}_{j}-\frac{\lambda}{\sigma+\epsilon} \Delta \log f_{j t}+e_{j 3}$,

(9b) $\Delta \log \mathrm{p}_{\mathrm{j}}=\mathrm{d}_{4}+\frac{\beta(\epsilon+\sigma(1-\lambda))}{\sigma+\epsilon} \mathrm{dem}_{\mathrm{j}}$

$$
-\frac{\epsilon+\sigma(1-\lambda)}{\sigma+\epsilon} \Delta \log \mathrm{f}_{\mathrm{jt}}+\mathrm{e}_{\mathrm{j} 4} \text {, }
$$

where $d_{3}$ and $d_{4}$ are constants and $e_{j 3}$ and $e_{j 4}$ are stochastic terms made up of the sampling errors in observed wages and employment rates and a term involving the error $u_{j}$ in equation (7). A comparison of $(9 a)$ and $(9 b)$ with $(8 a)$ and $(8 b)$ reveals that when wages are downward inflexible, the responsiveness of wages to negative supply or demand shocks is reduced, whereas the responsiveness of the employment rate to negative supply or demand shocks is increased.

Consider two economies that have the same taste and technology parameters, and are subject to the same pattern of (negative) demand shocks. For simplicity, assume that relative population shares are constant, so that the only shocks to either economy are relative demand shocks. Finally, assume that one economy has fully flexible relative wages, whereas the other is characterized by an inflexibility parameter $\lambda<1$. Then equations (9a) and (9b) imply that the effect of initial wages on relative wage changes is attenuated by a factor $\lambda$ in the inflexible economy, whereas the effect of initial wages on relative employment changes is expanded by a

\footnotetext{
${ }^{25}$ Note that if the optimal wage change is positive and wages only partially adjust then the observed wage outcome will be on the supply curve.
} 
factor of $(\epsilon+\sigma(1-\lambda)) / \epsilon$. Furthermore, in the flexible economy the ratio of the effects of the initial wage variable in the employment and wage change equations provides an estimate of the elasticity of labor supply $(\epsilon)$, whereas in the inflexible economy, this ratio is equal to $(\epsilon+\sigma(1-\lambda)) / \lambda$, which is strictly greater than $\epsilon$.

Our empirical strategy is to estimate models like (9a) and (9b) using observed changes in wages and employment-population rates over the 1980 s for different age-education groups in the United States, Canada, and France. Implicit in our approach is the assumption that the same pattern of relative labor demand shocks affected the three economies over this period. In other words, we assume that the coefficient $\beta$ in equation (7) is constant across countries. As noted in Section I, we believe there is a reasonable case for this assumption. If $\beta$ is not constant across countries, however, then the relative slopes of the wage and employment change models will reflect differences in both $\beta$ and $\lambda$.

\section{Microdata on Wages and Employment}

We have assembled labor market survey data for men and women from the beginning and end of the 1980s for the U.S., Canada, and France. Our samples include individuals age 16-65 in the United States, age 17-64 in Canada, and age 15-60 in France. We further limit our U.S. samples to whites, in order to abstract from issues of discrimination and/or differential productivity by race. A complete description of our data sources and selection criteria is presented in Appendix 1.

The surveys for each country measure employment status as of a particular survey week. In all cases, the wage measure is a "point-in-time" estimate of the usual hourly wage for an individual's main job. ${ }^{26}$ This measure differs from the one typically used in the literature,

\footnotetext{
${ }^{26}$ The French surveys collect usual monthly earnings and average hours per week, which we use to construct an hourly wage. The U.S. surveys collect usual hourly wages or usual weekly wages and usual hours per week, which we use to form an estimate of usual hourly pay. The two Canadian surveys ask about wage information for jobs held in the previous year, rather than currently. In all three countries, wages are unavailable for self-employed workers.
} 
which is constructed from annual earnings and weeks of work over the year. Nevertheless, comparisons of alternative wage measures for the U.S. labor market reported in Card and Lemieux (1995) suggest that the two types of measures give similar estimates of the levels and changes in hourly wages. In our U.S. and Canadian data sets, wages are recorded before taxes, whereas in our French data sets, wages are recorded net of employee payroll tax contributions. Since the French payroll tax is a fixed proportion of gross earnings, this difference should not affect relative pay comparisons.

Tables 5 and 6 present the overall levels and changes in mean log wages and employment rates estimated from our samples. As shown in row 8 of table 5 , mean log wages of men fell by 7.5 percent in our U.S. sample, rose by 3.9 percent in our Canadian sample, and fell by 2.7 percent in our French sample. For women, average real wage growth was slightly positive in the U.S. and Canada, and negative in France. ${ }^{27}$ The measured decline in real wages for French workers may appear anomalous, given that other wage series, such as the one presented in Figure 2 , show an increase over the same period. The difference is due to the use of an after-tax wage. Between 1982 and 1989, the employees' portion of the French payroll tax increased by 5 percentage points, from 13 to 18 percent. Thus the measured declines in real after-tax wages between 1982 and 1989 are consistent with roughly 3 percent increases in real before-tax wages - a comparable trend to other wage series.

The entries in row 9 of Table 5 show that the standard deviation of log wages grew by 15-20 percent between 1979 and 1989 in the United States, while this measure of wage inequality was roughly constant in Canada and rose only slightly in France. Rows 10-12 decompose the changes in the cross-sectional variances of wages in each country into a component attributable to changes in wage dispersion within narrowly-defined age-education cells, and a component attributable to changes in between-cell dispersion. The decompositions suggest that the sharp

${ }^{27}$ It is interesting to note that although the male-female wage gap closed by almost 10 percentage points in the U.S. in the 1980s, the gap was virtually constant in Canada and France. 
rises in wage inequality in the U.S. were about equally attributable to rising inequality within and between age-education groups. In Canada, the variances of wages between age-education cells rose only slightly less than in the United States. However, rising wage inequality between groups was counteracted by a decline in the within-cell variance of wages in Canada, leading to little net increase in overall dispersion.

Although it is possible that wage variation within age-education cells actually fell in Canada over the 1980s, an alternative explanation is that changes in survey procedures lowered the variability of survey-response errors. ${ }^{28}$ Unlike our U.S. and French samples, our Canadian samples are based on slightly different survey instruments in 1981 and 1988 . Nevertheless, we believe that changes in the Canadian survey should not have affected the estimated means by skill group, implying that our comparisons between skill groups are valid. We conclude that the variation in wages across different age-education groups increased in the United States and Canada over the 1980s and was roughly constant in France.

Turning to employment outcomes, the first two rows of Table 6 present average employment-population rates for the men and women in our samples at the beginning and end of the 1980s. As shown in row 3, male employment-population rates declined in all three countries during the decade, while female employment-population rates increased. Other things equal, changing age and education distributions over the 1980s would have been expected to lead to rising employment rates for both genders in all three countries. When we control for the effect of these changes (based on differences in the cross-sectional patterns by age/education at the start of the 1980s) the declines in employment for men are even more pronounced, while the increases for women are reduced -- see row 4. For comparative purposes, we also repor the overall changes in employment-population rates by gender over the same sample periods in row 5. These tend to be fairly similar to the adjusted changes from our sample.

\footnotetext{
${ }^{28}$ Since the age-education cells in Canada contain a wider range of ages and education levels than in the United States, one might have actually expected a bigger increase in within-cell dispersion in Canada.
} 
In our empirical analysis we aggregate the micro-level data for the three countries into age-education cells and compare changes over time in the employment rates and mean wages of different cells. Figures 4-6 illustrate some of the basic patterns in the cell-level data. The figures plot the changes in wages and employment rates for each cell against the mean wage of the cell at the beginning of the 1980s. For reference, we have added a line to each figure representing the increase in nominal wages that would have been required to maintain a constant real wage.

As shown in Figure 4, the U.S. data show a strong positive correlation between the wage growth experienced by a given age-education group over the 1980s and the initial level of wages of the group in 1979. Among men (in the upper panel) only a few cells had average wage increases large enough to maintain the real value of their earnings. More of the female ageeducation groups had nominal wage growth in excess of inflation. On the employment side, the scatter of points in the upper panel of Figure 4 shows little correlation between the initial level of wages for different groups of men and the change in their employment rate, while the correlation across different groups of women (in the lower panel) is stronger.

The data for Canadian men and women in Figure 5 show some similarities with the U.S. data. For both genders, age-education groups with higher initial wages tended to have faster wage growth over the 1980s, although relative to the U.S. the correlation is less pronounced. The pattern of employment changes across groups is also less systematic in Canada. Indeed. the employment data in the upper panel of Figure 5 suggest that groups of lower-wage men in Canada tended to have bigger employment gains than groups of higher-wage men. Nixice. however, that this pattern is driven by a few low-wage cells: these are made up of younger and less-educated workers who experienced large wage losses and significant employment gauns over the 1980 s.

Figure 6 shows that the patterns of relative wage changes in France over the 1980s were quite different from those in the U.S. or Canada. Unlike their counterparts in North America, 
French workers with relatively low wages at the beginning of the 1980s had about the same rate of wage growth as those with relatively high wages. Assuming that French employers were affected by the same demand shocks as employers in the United States and Canada, this pattern suggests substantial relative wage inflexibility. On the other hand, the patterns of employment growth across different age-education cells in France are fairly similar to those in the U.S. or Canada.

\section{Models of Relative Changes in Wages and Employment Rates}

Table 7 presents estimates of equations ( $8 a$ ) and ( $8 b$ ), fitted to the cell-level data for each country using two alternative proxies for the relative demand shocks faced by different ageeducation groups: the mean log wage of the group at the beginning of the 1980s; and the fraction of the group who used a computer at the end of the 1980s. For each demand proxy we present two estimates of equation (8a): one using the actual change in mean log wages of workers in the cell (columns 1 and 4); and another using an adjusted wage measure that assigns the minimum wage to non-workers (columns 2 and 5). ${ }^{29}$ All the models are fit by weighted least squares, using as a weight the fraction of the adult population in the age-education cell in the base period. ${ }^{30}$

The models in column 1 of Table 7 regress the changes in mean cell wages for a given country and gender group on the initial cell wage and the change in the population fraction of the group. The coefficients of the mean cell wage variable are large and positive for U.S. and Canadian men and women, but are actually negative for French men $(-0.01)$ and women $(-0.12)$.

\footnotetext{
${ }^{29}$ We have also estimated the wage models using the 50th and the 75th percentiles of wages for each cell (constructed over workers and non-workers, assuming that non-workers are below the median). The estimates (summarized in Appendix Table 2) are very similar to those in Table 7.

${ }^{30}$ The parameter estimates tend to be very similar regardless of whether the estimated are obtained by unweighted least squares, or by weighted least squares with any of a variety of cell weights
} 
The signs and magnitudes of the estimated coefficients are not too different when we account for potential selectivity biases by assigning the minimum wage to non-workers in each cell (column 2).

The models in column 3 regress the change in the employment-population rate on the same explanatory variables. For U.S. men, the coefficient is positive (0.04) and marginally significant while for U.S. women, the coefficient is larger (0.12) and highly significant. Together with the estimates in column 1, these estimates support the conventional view that relative demand shocks reduced the demand for less-skilled workers of both genders, leading to relative declines in wages and employment. According to equations (8a) and (8b), the ratio of the coefficients of the relative demand index in models for the change in log employment and the change in log wages is an estimate of the labor supply (participation) elasticity. The estimates for U.S. men imply an elasticity of 0.21-0.24, while the estimates for U.S. women imply an elasticity of $0.32-0.40$.

The estimates in column 3 for Canada and France are much harder to interpret. Even though higher-wage workers in Canada had larger relative wage gains over the 1980s, the change in employment is insignificantly or even negatively related to the base wage level. In France, where relative wage growth was fairly even across skill groups, the change in employment is also only weakly related to the base wage level. There is no evidence that the rigidity of French relative wages gave rise to "excess" employment losses for workers whose relative wages would have been predicted to fall on the basis of U.S. patterns.

The models in columns 4-6 of Table 7 regress the changes in wages and employment rates on the alternative demand index variable based on observed computer use rates at the end of the 1980s. The general patterns and implications of the estimated coefficients are not too different from those in columns 1-3. Among U.S. men, for example, the coefficients relating wage and employment changes to computer use rates are slightly larger than the coefficients relating these outcomes to the base wage level, but their ratio is similar, implying a similar supply elasticity. 
Experiments with other specifications revealed that the estimated demand-index coefficients for the models in Table 7 are sensitive to two issues: whether or not cells of very young and very old workers are included ${ }^{31}$; and whether or not the change in population share is included as an additional control variable. Our theoretical model suggests that age-education cells that increased their relative population shares should have had slower wage and employment growth rates. Contrary to this prediction, the estimated coefficients of the population share variables are mainly positive, and over one-half of the estimates are significant. This constitutes fairly strong evidence against our simple theoretical model.

One explanation for the "wrong sign" on the supply-side shift variables is that the wages of a narrow skill group may depend on a broader index of supply that the relative population share of the group. In a more general model, workers in a given age-education cell may be good substitutes for workers with similar levels of age and education, in which case the relative population shares of the substitute groups must also be included in the reduced-form employment and wage models.

Table 8 presents an alternative set of estimates of the wage and employment change models, excluding the population share variable. We present estimates for both sexes using all the available age-education cells, and using only the subset of men age 25-54. For the U.S. samples, the estimated coefficients are fairly similar across specifications. The estimated effects of either demand index on both employment and wage growth are positive and significant. Furthermore, the implied estimates of the labor supply elasticities are quite stable, ranging from 0.2 to 0.5 across the different specifications.

The estimated coefficients for the Canadian samples tend to be slightly smaller when the computer use rate is used as a relative demand index than when the average wage in the early 1980 s is used as a relative demand index. Furthermore, the estimates of the employment

\footnotetext{
${ }^{31}$ This sensitivity is particularly notable for the Canadian models, which are estimated on relatively few cells.
} 
equation for Canadian men using the base wage as a demand index are quite sensitive to the exclusion of some cells of younger and old men. Focussing on the results for women and prime age men, however, two conclusions emerge. First, relative to the U.S. benchmark, wages of different age and education cells in Canada were somewhat less responsive to relative demand shocks. For example, the ratio of the wage coefficients for Canadian women to the corresponding coefficients for U.S. women is between 0.25 and 0.76 . This is consistent with some modest dampening of relative wage responses by Canadian labor market institutions. Second, relative employment patterns across different age-education groups in Canada are similar to those in the U.S. There is no hint of "excess sensitivity" of relative employment to relative demand shocks, as might be expected if relative wages are somewhat inflexible.

The results for France in Table 8 confirm that wage differentials across different ageeducation groups were relatively stable over the 1980s. If anything, average wage changes for men and women tend to be negatively correlated with our relative demand indexes. One possible explanation for these negative coefficients is that other institutional factors, such as increasing unemployment benefits, have compressed the structure of wages. Under the assumption that France was affected by the same relative demand shocks as Canada and the United States, the estimates in Table 8 suggest extreme relative wage rigidity. On the other hand, the employment coefficients for France are very similar to those for the U.S. and Canada. The average of the coefficients for the three employment models using the base wage as a relative demand index is 0.10 in the U.S., 0.0 in Canada ( 0.08 excluding the estimate for all men), and 0.06 for France. The average of the coefficients for the three employment models using the computer usage rate as a demand index is 0.14 in the U.S., 0.10 in Canada, and 0.12 for France. 


\section{E. Estimates of the Structural Parameters}

The theoretical model of wage and employment determination presented in Sections II.A and II.B provides a convenient framework for interpreting the estimated coefficients of the demand index variables in Tables 7 and 8. Assuming that relative demand shocks were similar in the three countries, and that Canada and France have relative wage flexibility parameters $\lambda_{C}$ and $\lambda_{F}$, respectively, the wage and employment coefficients for the 3 countries depend on five structural parameters: the elasticity of substitution $(\sigma)$, the labor supply elasticity $(\epsilon)$, the two flexibility parameters, and the parameter used to predict relative demand shocks with either the base period wage or the computer use rate $(\eta)$. For a given choice of the relative demand index the model is over-identified, since the six reduced form coefficients for wages and employment - two for each of the three countries -- depend on only five structural parameters. ${ }^{32}$

Table 9 reports the estimates of the structural parameters derived from six multivariate reduced-form models for three gender/age groups (all men, men age 25-54, and women) using two alternative demand indexes. The parameters are estimated by minimum distance using the unrestricted reduced form estimates presented in Table $8 .^{33}$ (For simplicity, we only repon models that use the selection-adjusted wage changes). Of the six restricted models estimated in the Table, only one is rejected by an over-identification test -- the model for all men that uses the base period wage as a relative demand index. The "problem" for this model is the negatuve and significant estimate of the effect of the base period wage on the change in employment for Canadian men. Given the small number of age-education cells in our Canadian sample. and the results for 25-54 year old men, we believe that this estimate can be ignored.

\footnotetext{
${ }^{32}$ Note that we do not attempt to estimate a joint model for the coefficients of the demand indexes and the relative population share variables.

${ }^{33}$ The estimated structural parameters are obtained by minimizing the weighted distance between the six reduced form parameters and what the structural model predicts these parameters should be. The metric used to compute the distance (weighting matrix) is a diagonal matrix whose diagonal elements are the inverse of the variances of the estimated reduced form parameters.
} 
The five other estimated models (columns 2 to 6 ) yield a fairly coherent interpretation of the data. As expected, wages are less flexible in Canada than in the United States and even less flexible in France. The estimate of the wage flexibility parameter for Canada ranges from 0.37 to 0.88 and is significantly different from 0 and 1 in four cases out of five. The estimate of the wage flexibility parameter for France is always negative, although not ridiculously far from 0. Notice also that the labor supply elasticities are within the $0.2-0.4$ range, which is roughly consistent with the existing literature. What is more difficult to explain are the small and often negative estimates of the substitution elasticity $(\sigma)$. Since the labor demand elasticity is the inverse of $\sigma$, these estimates imply that the labor demand curve is approximately vertical. In the model of equation (9b), the employment effect of a demand shift depends on the degree of wage flexibility $\lambda$ except in the case where the labor demand curve is vertical $(\sigma=0)$, and wages play no role in employment determination. By setting $\sigma$ close to 0 , the structural models "explain" the fact that although relative wages are less flexible in Canada or France than in the U.S., the patterns of relative employment growth are very similar across the three countries.

\section{Conclusions}

This paper is motivated by a very simple observation: in labor markets with rigid relative wages, negative employment demand shocks will lead to larger employment losses for the affected groups of workers than would be expected if wages could freely adjust. We test this prediction by comparing changes in wages and employment rates for different age and education groups over the 1980s in the United States, Canada, and France. We argue that the same forces that are generally believed to have lowered the real wages of less-skilled workers in the U.S. labor market have affected labor markets in Canada and France. In comparison to the U.S. labor market, however, Canada and especially France have a variety of institutional features that tend to prevent relative wage adjustments. We would therefore expect the relative structure of wages 
to have changed less in Canada and France than in the United States during the 1980s, but the relative structure of employment to have changed more.

Using comparable micro-data from the beginning and end of the 1980s for each country, we relate changes in wages and employment-population rates for narrow age and education cells to two proxies for skill-group-specific relative demand shocks: the initial level of wages for the group, and the fraction of the group who were using computers at the end of the 1980s. In the United States, wage changes over the 1980s were highly correlated with these two variables: higher-wage groups and those that were more likely to adopt computer technologies enjoyed bigger wage gains, while lower wage groups and those that were less likely to adopt computers suffered significant real wage declines. We find a slightly weaker relationship between these two variables and wage growth in Canada, and virtually no relation in France. Thus, relative wages appear to be slightly less flexible in Canada than the United States, and to be completely inflexible in France.

The patterns of relative employment changes do not support the view that wage flexibility moderates the employment losses for groups affected by negative demand shocks. In the United States, the relative employment rates of lower-wage groups declined over the 1980s. As has been noted in previous work (Juhn (1992)), the parallel trends in wages and employment rates for less-skilled workers are consistent with movements along an upward-sloping supply schedule. In Canada and in France, where one might have expected relative wage rigidity to lead to even bigger employment losses for low-wage workers, the patterns of relative employment growth over the 1980s are virtually identical to those in the United States. We conclude that the inflexibility of relative wages in Canada and France does not seem to have distorted the pattern of relative employment losses. 
References

Baker, Michael, Dwayne Benjamin, and Shuchita Stanger. "The Highs and Lows of the Minimum Wage Effect: A Time Series-Cross Section of the Canadian Law" University of Toronto Department of Economics Unpublished Research Paper, 1994.

Bayet, Alain. "Les salaires de 1991 à 1993 dans le secteur privé et semi-privé. INSEE Résultats. Paris: INSEE, 1994.

Bank of Canada. Bank of Canada Review. Ottawa: Bank of Canada, Autumn 1994.

Berman, Eli, John Bound, and Zvi Griliches, "Changes in the Demand for Skilled Labor within U.S. Manufacturing: Evidence from the Annual Survey of Manufactures." Quarterly Journal of Economics 109 (May 1994): 367-98.

Bhagwati, Jagdish and Vivek Dehejia. "International Trade Theory and Wages of the Unskilled." In Marvin H. Kosters and Jagdish Bhagwati, editors, Trade and Wages. Washington D.C.: American Enterprise Institute, 1994.

Borjas, George J. and Valerie A. Ramey. "Foreign Competition, Market Power, and Wage Inequality: Theory and Evidence." National Bureau of Economic Research Working Paper No. 4556, December 1993.

Borjas, George J. and Valerie A. Ramey. "Time Series Evidence on the Sources of Trends in Wage Inequality." American Economic Review Papers and Proceedings 84 (May 1994): 10-16.

Bound, John and George Johnson. "Changes in the Structure of Wages in the 1980s: An Evaluation of Alternative Explanations". American Economic Review 82 (June 1992): 371-392.

Canada Department of Finance. Quarterly Economic Review (June 1991 edition). Ottawa: Department of Finance.

Card, David and Alan Krueger. Myth and Measurement: The New Economics of the Minimum Wage. Princeton: Princeton University Press, 1995.

Card, David and Thomas Lemieux. "Wage Dispersion, Returns to Skill, and Black-White Wage Differentials." Joumal of Econometrics forthcoming 1995.

Card, David and W. Craig Riddell. "A Comparative Analysis of Unemployment in the United States and Canada." In David Card and Richard B. Freeman, editors, Small Differences that Matter: Labor Markets and Income Maintenance in Canada and the United States. Chicago: University of Chicago Press, 1993.

Card, David and Rebecca Blank. "Recent Trends in Insured and Uninsured Unemployment: Is There An Explanation?" Quarterly Journal of Economics 106 (November 1991).

Freeman, Richard B. "How Labor Fares in Advanced Countries." In Richard B. Freeman, editor, Working Under Different Rules. New York: Russell Sage Foundation, 1994.

Freeman, Richard B. and Karen Needels. "Skill Differentials in Canada in an Era of Rising Labor Market Inequality." In David Card and Richard B. Freeman, editors, Small Differences 
that Matter: Labor Markets and Income Maintenance in Canada and the United States. Chicago: University of Chicago Press, 1993.

Haeusler, Laurence. "Le Monde Associatif de 1978 à 1986." Donnés Sociales (1990 edition). Paris: INSEE, 1990.

Institut National de la Statistique et des Etudes Economiques (INSEE). "Enquête sur l'Emploi de 1982, Résultats détaillés," les collectionss de l'INSEE. Paris: INSEE, 1989.

Institut National de la Statistique et des Etudes Economiques (INSEE). "Enquête sur l'Emploi de 1989, Résultats détaillés," INSEE Résultats, Emploi-Revenus, vol 6-7. Paris: INSEE, 1989.

Institut National de la Statistique et des Etudes Economiques (INSEE). Annnuaire Statistique de la France (various years). Paris: INSEE.

Juhn, Chinhui. "Decline of Male Labor Market Participation: The Role of Declining Market Opportunities." Quarterly Joumal of Economics 107 (February 1992): 79-122.

Juhn, Chinhui, Kevin M. Murphy and Brooks Pierce. "Wage Inequality and the Rise in Returns to Skill". Joumal of Political Economy 101 (June 1993): 410-442.

Katz, Lawrence F., Gary W. Loveman, and David G. Blanchflower. "A Comparison of Changes in the Structure of Wages in Four Countries." National Bureau of Economic Research Working Paper No. 4297, March 1993.

Kosters, Marvin H. "Changing Wage Patterns in the Labor Market: The Main Results of Research." In Marvin H. Kosters and Jagdish Bhagwati, editors, Trade and Wages. Washington D.C.: American Enterprise Institute, 1994.

Krueger, Alan B. "How Computers Have Changed the Wage Structure: Evidence from Microdata, 1984-1989". Quarterly Joumal of Economics 108 (February 1993): 33-60.

Krugman, Paul. "Inequality and the Political Economy of Eurosclerosis" Center for Economic Performance Discussion Paper, 1993.

Lawrence, Robert Z. "Trade, Multinationals, and Labor." National Bureau of Economic Research Working Paper No. 4836, August 1994.

Lawrence, Robert Z. and Matthew Slaughter. "Trade and U.S. Wages in the 1980s: Giant Sucking or Small Hickup?" Brookings Papers on Economic Activity: Microeconomics. 1493.

Leamer, Edward. "Trade, Wages and Revolving Door Ideas." National Bureau of Economic Research Working Paper No. 4716, April 1994

Lemieux, Thomas. "Unions and Wage Inequality in Canada and the United States." In David Card and Richard B. Freeman, editors, Small Differences that Matter: Labor Markets and Income Maintenance in Canada and the United States. Chicago: University of Chicago Press. 1993.

Lowe, Graham S. "Computers in the Workplace." Perspectives on Labor and Inceme 3 (Summer 1991): 38-50. 
Murphy, Kevin M. and Finis Welch. "The Role of International Trade in Wage Differentials." In Marvin H. Kosters, editor, Workers and Their Wages. Washington D.C.: American Enterprise Institute, 1991.

Murphy, Kevin M. and Finis Welch. "The Structure of Wages". Quarterly Journal of Economics 107 (February 1992): 285-326.

Nickell, Stephen and Brian Bell. "The Collapse in Demand for the Unskilled and Unemployment Across the OECD." Oxford Review of Economics Policy 11 (1995): 40-62.

Organization for Economic Cooperation and Development (OECD). Main Economic Indicators. 1991. Paris: OECD, 1991.

Organization for Economic Cooperation and Development (OECD). The OECD Jobs Study: Facts. Analysis, Strategies. Paris: OECD, 1994.

Price, Robert. "Trade Union Membership." In R. Bean, editor, International Labor Statislics. London: Routledge, 1989.

Riddell, W. Craig. "Unionization in Canada and the United States: A Tale of Two Countries." In David Card and Richard B. Freeman, editors, Small Differences that Matter: Labor Markets and Income Maintenance in Canada and the United States. Chicago: University of Chicago Press, 1993.

Statistics Canada. Canada Year Book (various years). Ottawa: Statistics Canada.

United States Department of Commerce Economics and Statistics Administration. Statistical Abstract of the United States (various years). Washington D.C.: USGPO.

United States Department of Labor, Bureau of International Affairs. Foreign Labor Trends: France. (FLT 93-40). Washington D.C.: USGPO, 1992.

United States Office of the President. Economic Report of the President (1994 adition). Washington D.C.: USGPO.

West, E.G., and Michael McKee. Minimum Wages: The New Issues in Theory, Eyidence. Policy and Politics. Ottawa, Canada: Economic Council of Canada and the Institute for Research on Public Policy, 1980. 


\section{APPENDIX 1: Data Description}

\section{A. Wage and Employment Data}

The U.S., Canadian, and French micro-data used in this paper are derived from supplements to the regular labor force surveys in each country. The surveys from all three countries provide a measure of usual hourly earnings for the respondent's main job last week (last month in France) for individuals who were working for pay and not self-employed.

Our U.S. analysis is based on merged monthly files for the outgoing rotation groups of the 1979 and 1989 Current Population Surveys (CPS). These files contain approximately 275,000 observations per year. We include in our samples men and women age 16 to 65 whose potential labor market experience (age-education-6) is positive. The employment rate is based on labor force activity in the survey week of the CPS. Our wage measure is based the reported hourly wage (for hourly-rated workers) or the ratio of reported weekly earnings to average weekly hours (for others). To limit the influence of outliers we have deleted all wage observations below $\$ 2.01$ or above $\$ 60.00$ in constant 1989 dollars in the wage analysis. We have also excluded from our wage samples any allocated wage observations.

To implement the estimation methods described in Section II we divided individuals of each gender into 225 individual age and education cells. The cells are based on single years of education (with $\leq 8$ years in the lowest cell and $\geq 18$ years in the highest cell) and 1, 2 or 3 year age ranges (single-year age ranges for ages up to 23, 2-year age ranges for ages 24 to 43 , and 3-year age ranges for ages 44 and older). We then computed the mean log wage, the employment rate, and other statistics for each cell.

Our analysis for France is based on data from the 1982 and 1989 Labor Force Survey (Enquête Emploi, EE) which is conducted every year by the French National Statistical Institute (see INSEE (1989) for technical details on the survey). The EE is a 1/300 sample of the French population, based on a three-year rotating panel. Seven panels of approximately 30,000 individuals age 15 to 60 are available over the 1981-89 period. We use a sample of 
60,723 observations for 1982 (based on all individuals in their first or second interview year in 1982) and 29,198 observations for 1989 (based on all individuals in their third interview year in 1989).

The EE collects information on usual monthly earnings net of payroll taxes for the respondent's main job last month. The variable is divided into the nineteen categories: less than $1,000 \mathrm{FF}$; from 1,000 to $1,500 \mathrm{FF}$; from 1,500 to $2,000 \mathrm{FF}$; ...; from 4,500 to $5,000 \mathrm{FF}$; from 5,000 to $6,000 \mathrm{FF}, \ldots$; from 9,000 to $10,000 \mathrm{FF}$; from 10,000 to $15,000 \mathrm{FF} ; \ldots$; from 25,000 to $30,000 \mathrm{FF}$; above $30,000 \mathrm{FF}$. Individuals who refuse to answer the earnings question are excluded from the wage samples.

Usual hourly earnings are obtained by dividing the midpoint of the earnings category by usual weekly hours times 4.33 (weeks per month). For both men and women, we divide the sample into 70 individual age and education cells, based on eight level of educational qualifications (no diploma, primary school (CEP), junior high school (BEPC), vocational or technical school (CAP), academic high school (baccalauréat), technical baccalauréat, undergraduate studies (academic or professional), and graduate studies or grandes écoles) and 5-year age ranges. We use coarser age-education cells in France than in the United States to allow a reasonble number of observations per cell.

Our Canadian analysis is based on Statistics Canada's 1981 Survey of Work History (SWH) and 1988 Labour Market Activity Survey (LMAS). The two surveys are retrospective supplements to the regular Labor Force Survey that were conducted in January 1982 and February 1989. The 1981 SWH and the 1988 LMAS yield samples of 61,066 and 58,860 individuals aged $16-64$ respectively.

The SWH and the LMAS collect information on hourly or weekly wages and usual hours of work for each job in the previous year. We have edited the Canadian samples to obtain samples comparable to those collected in the CPS and EE. For each month (in the SWH) or week (LMAS) of the year we determined the main job (if any) based on reported 
hours for all jobs held in that month or week. Each main job held at some time in the previous year was then assigned a weight based on the fraction of the year that this job was the respondent's main job. The final sample is a sample of main jobs with weights that represent the probability that the job would appear in a sample of ongoing jobs conducted at regular intervals over the year. This "weighted sample" is thus comparable to the samples obtained in CPS or the EE. We use a similar procedure to compute an employment rate comparable to the employment rate obtained in the CPS or in the EE.

A major limitation of the Canadian samples is that only broad age and education categories are available in the public use versions of the 1981 3 WH and 1988 LMAS: five education categories (primary education or less; some or completed high school; some postsecondary education; post-secondary diploma or certificate; university degree); and six age ranges $(17-19,20-24,25-34,35-44,45-54$, and 55-64). Excluding university graduates aged 17-19, we thus have 29 age-education cells. Note finally that there is no earnings allocation flag in the public use samples. We thus keep allocated wage information in Canadian samples.

\section{B. Data on Computer Use at Work}

The proportion of workers using computers at work in each age-education cell is obtained using U.S. data from a supplement to the April 1989 CPS, French Data from the 1991 Enquête-Emploi, and Canadian data from the 1989 General Social Survey (GSS).

Details on the CPS and the Enquête-Emploi are provided above. The GSS is a survey of approximately 10,000 individuals conducted by Statistics Canada. The 1989 GSS included several questions on technology at work, including the use of a computer. The age categories in the GSS, the SWH, and LMAS are identical, while education categories are more detailed in the 1989 GSS. Workers in the GSS can thus be divided in the same 29 age-education cells used to divide the SWH and LMAS samples. 
Appendix 2: Estimated Regression Models for Changes in Various Selection Adjusted and Unadjusted Measures of Wages for Men and Women: United States, Canada, and France

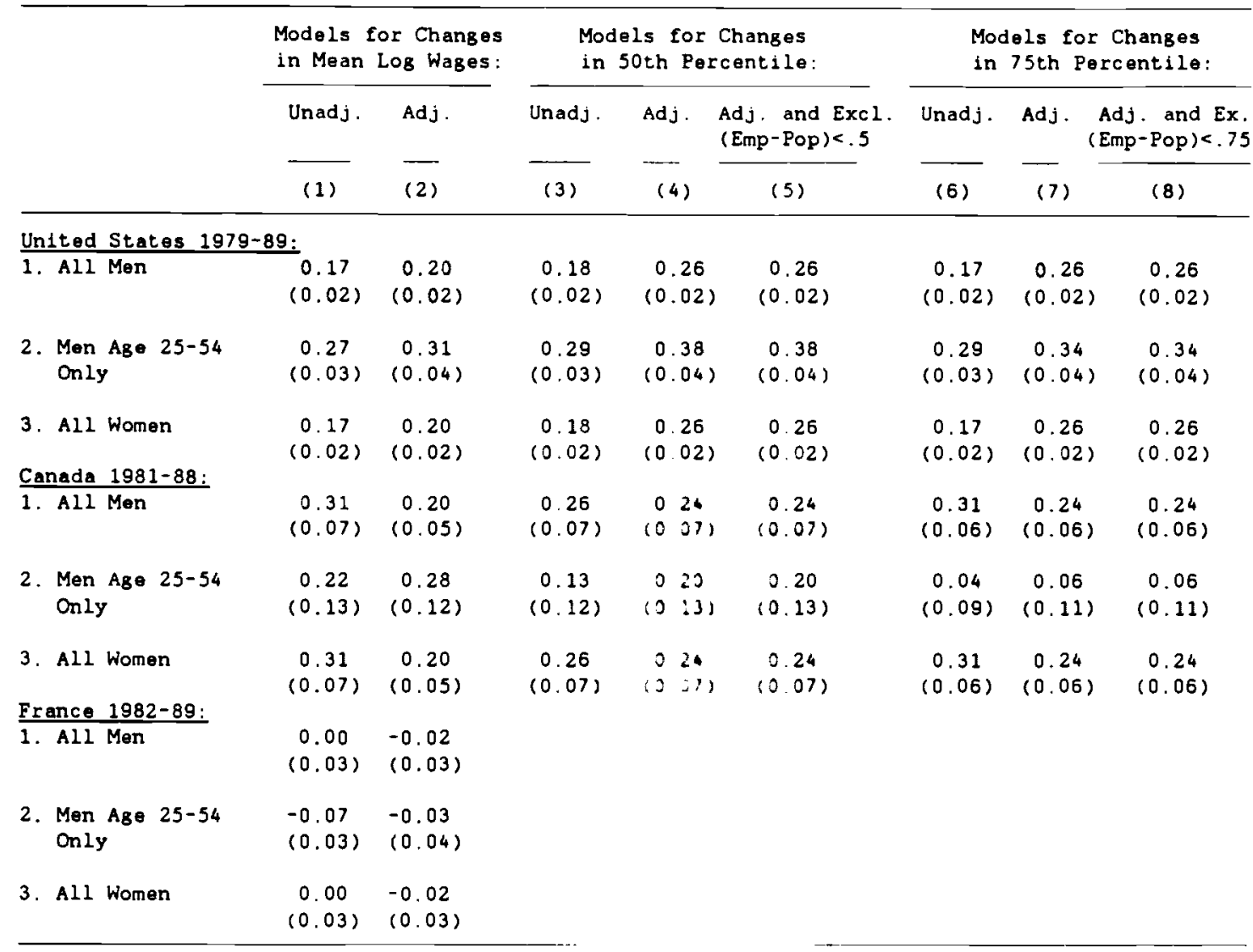

Notes: Standard errors in parentheses. See note :0 :ab:0,

In column 1 the dependent variable is the cterese in the mean cell wage between the base year and the end year. In colum 2 the jefer.lene varlable is the change in the mean cell wage, assuming that those who don't work earn the minimum wage in the respective year. In colum 3 the dependent variable is the tarese in the median wage among workers. In column 4 the dependent variable is the cherce in the median wage in the population, assuming that those who don't work earn $: 1 . n: n: m$ wage. The same dependent variable in used in column 5 but cells in which less ine ' 2 fercent of the population is employed in either the base or the end year are exc:.:1 : 1 . imms 6 to 8 the dependent variable is as in columns 3 to 5 except that the - : : en : : eplace by the 75 th percentile. 


\section{Figure 1}
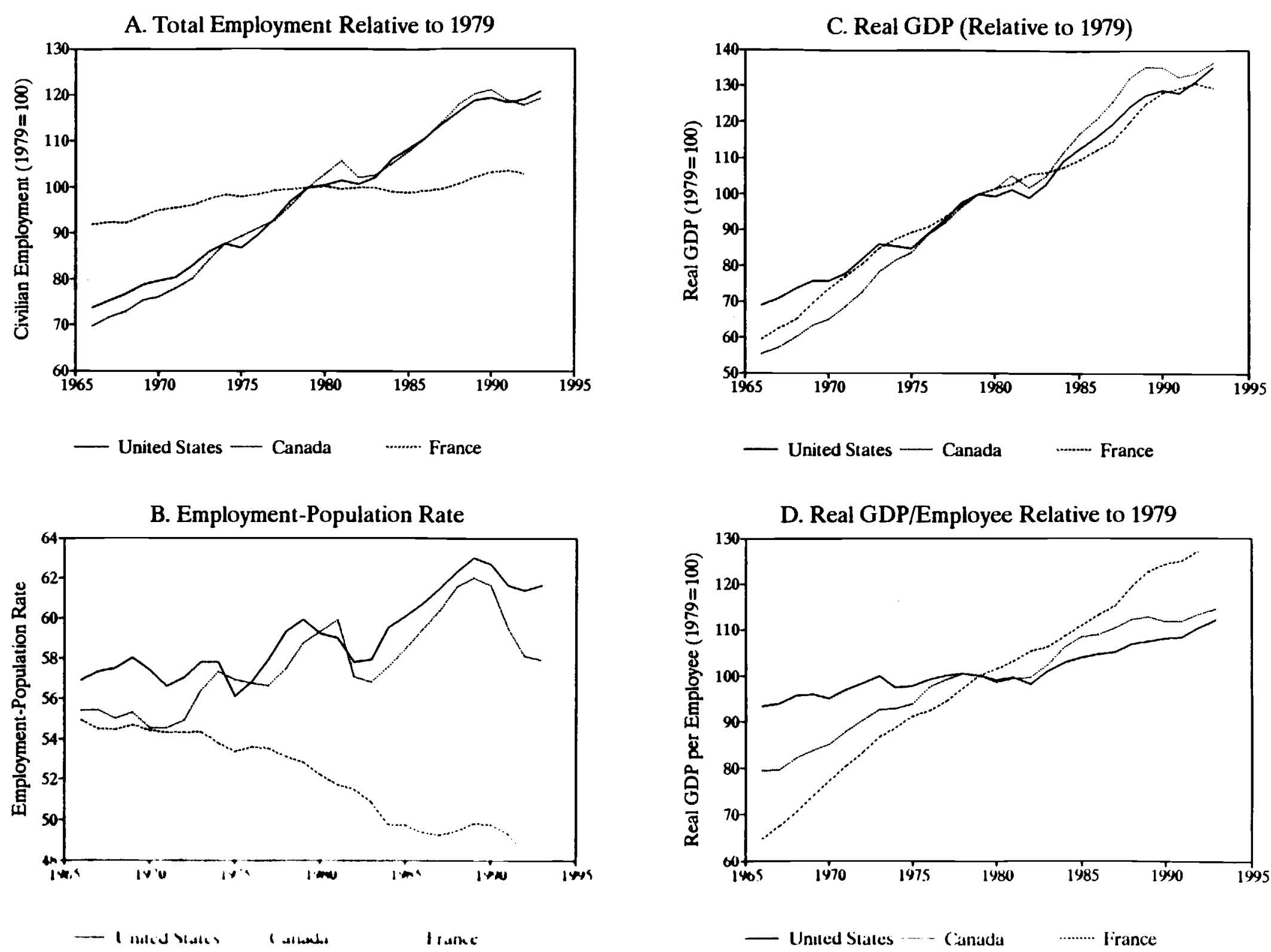
Figure 2

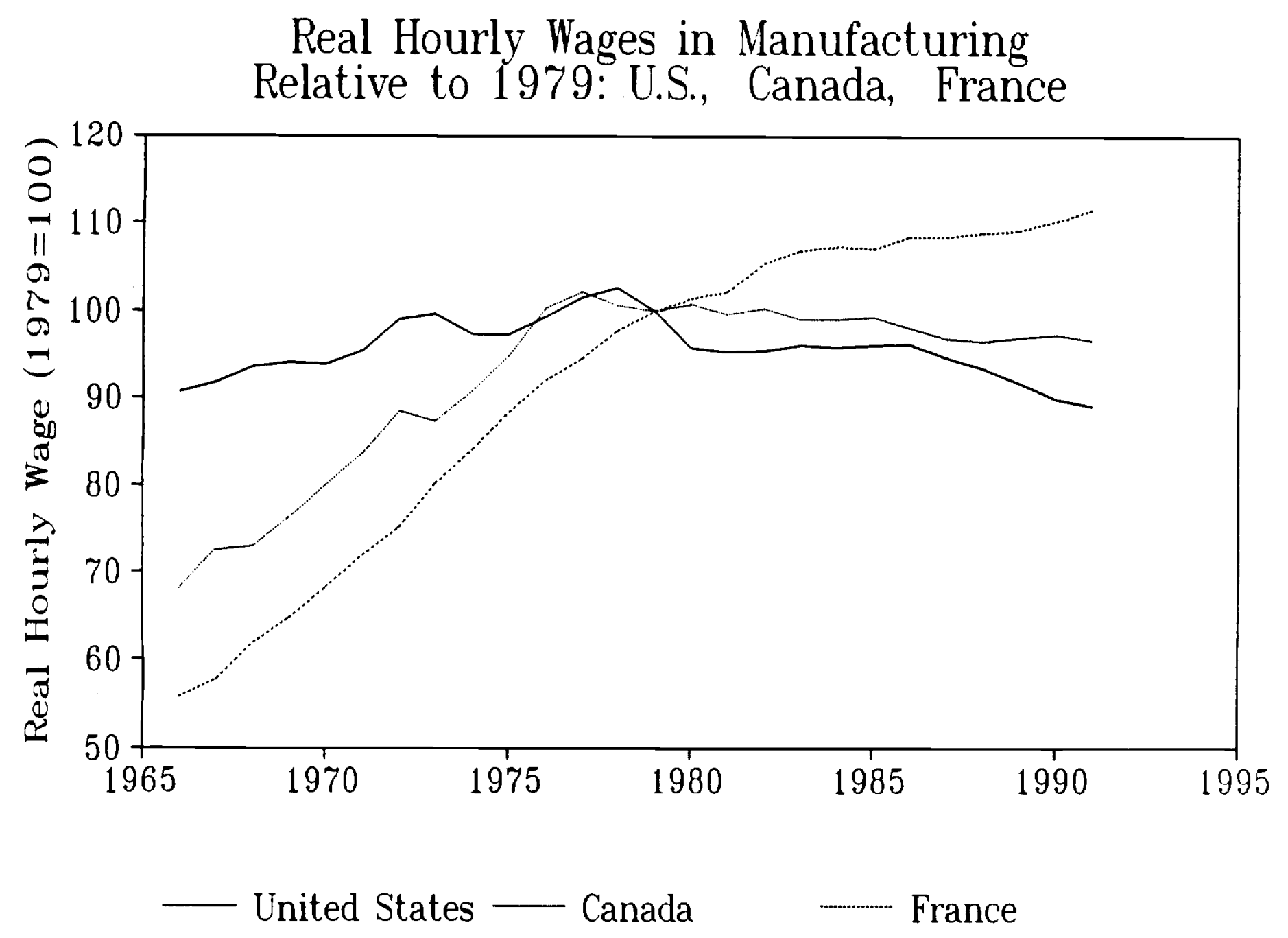


Figure 3

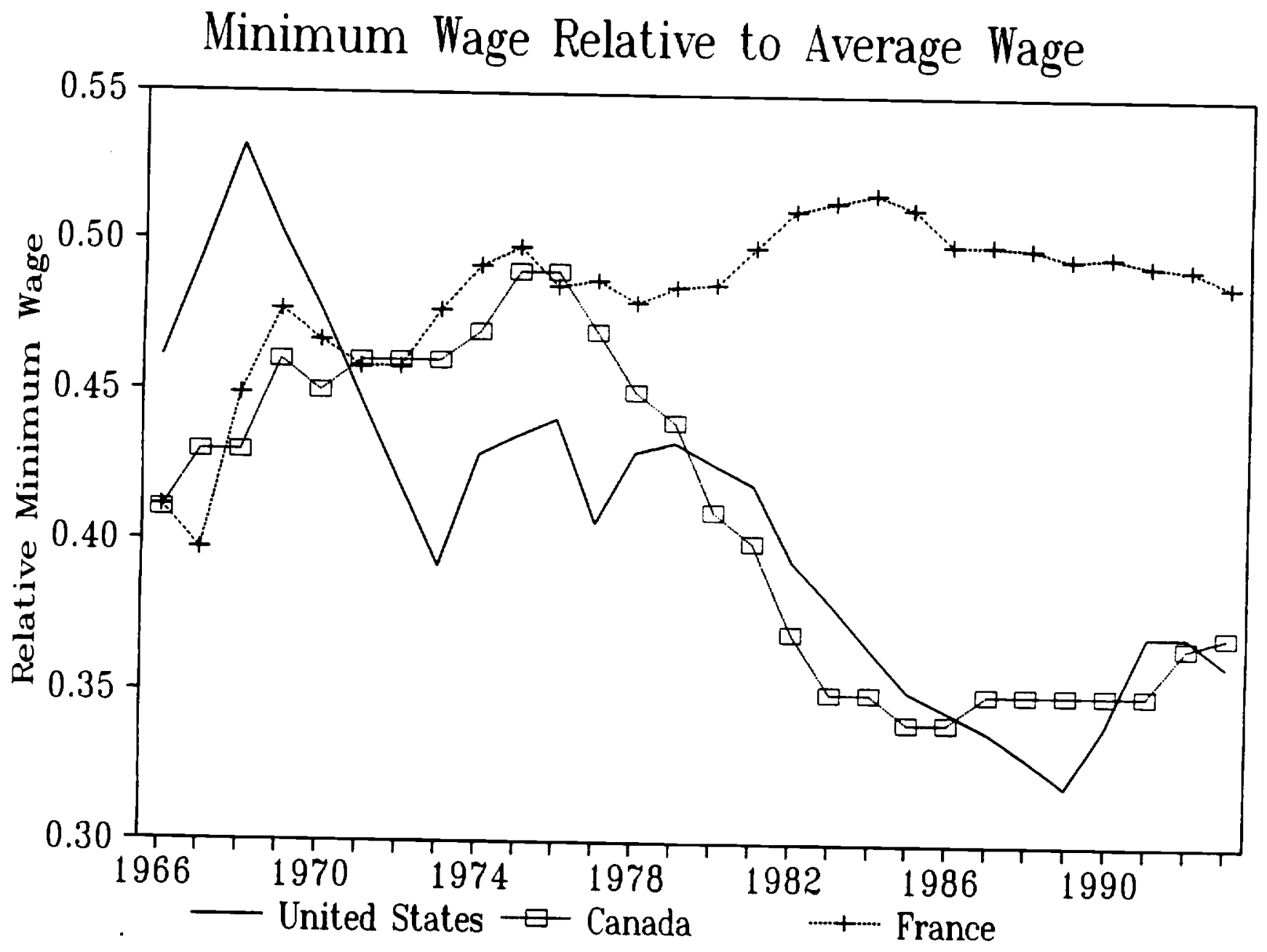

Note: minimum wage relative to average manufacturing wage in U.S. and Canada and relative to overall average wage in France. 

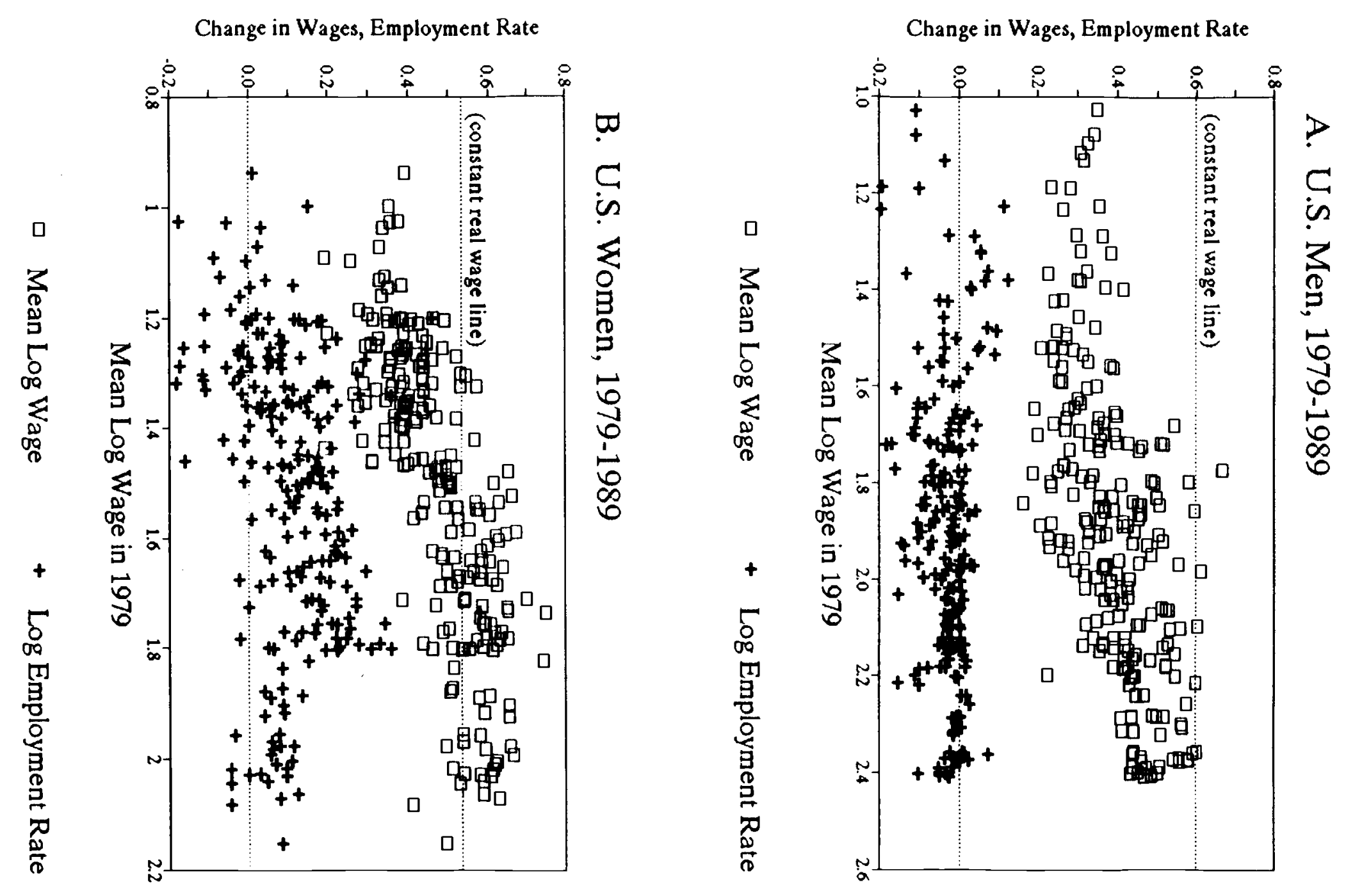
Figure 5: Changes in Employment and Wages Over the 1980s Men and Women in Canada

A. Canadian Men, 1981-1988

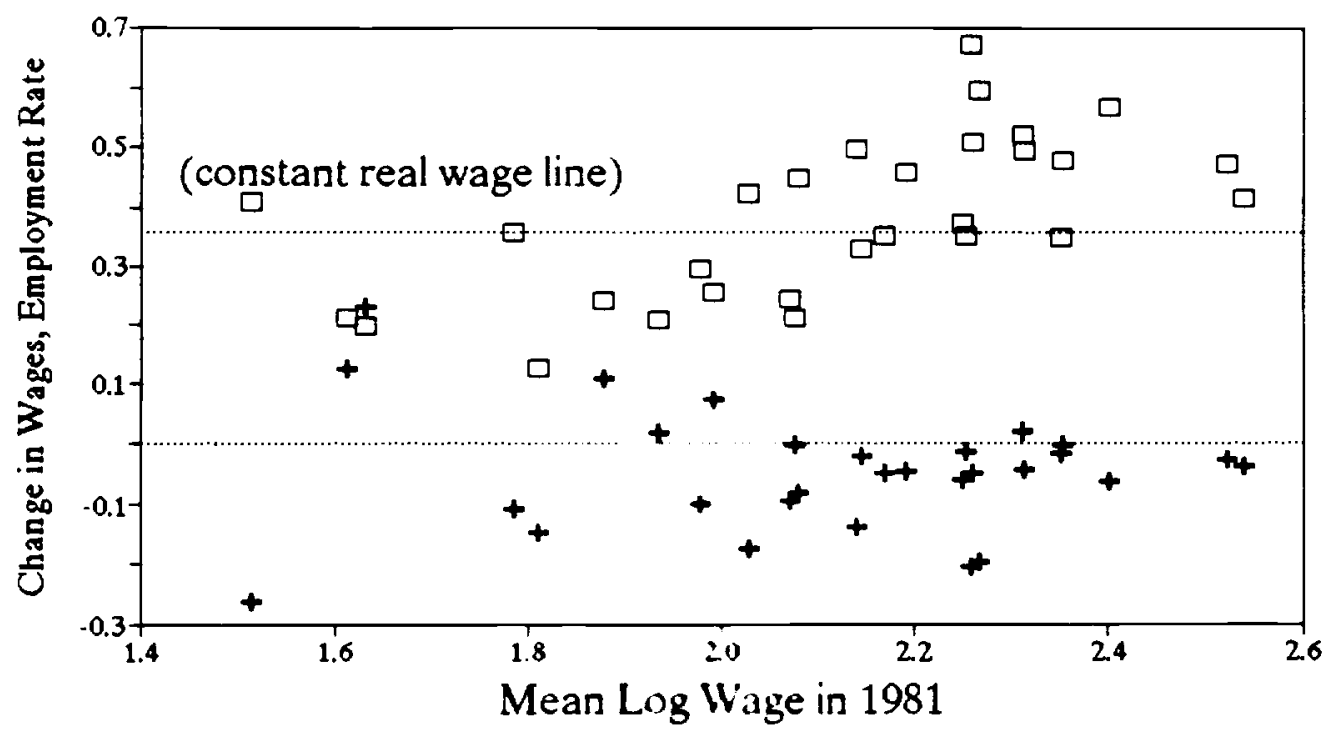

Mean Log Wage + Log Employment Rate

B. Canadian Women, 1981-1988

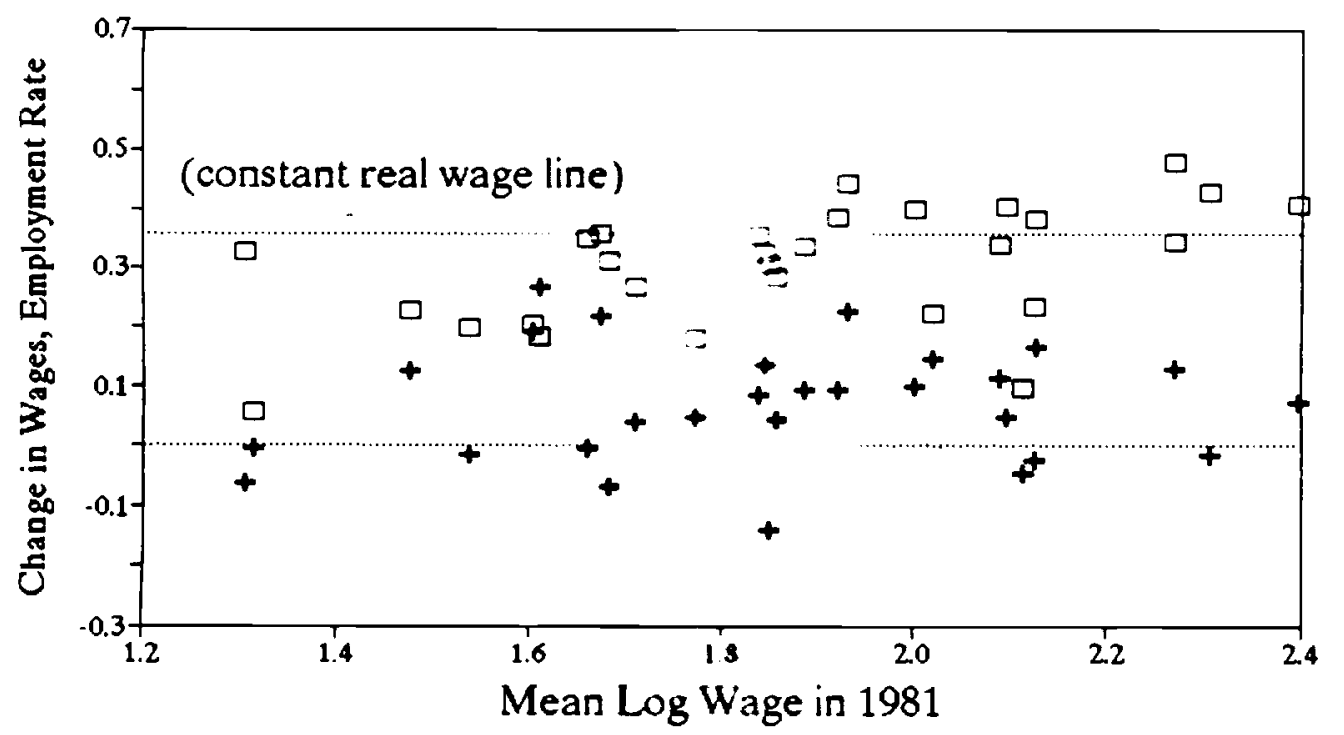

$\square$ Mean Log Wage + Log Employment Rate 
Figure 6: Changes in Employment and Wages Over the 1980s Men and Women in France

A. French Men, 1982-1989

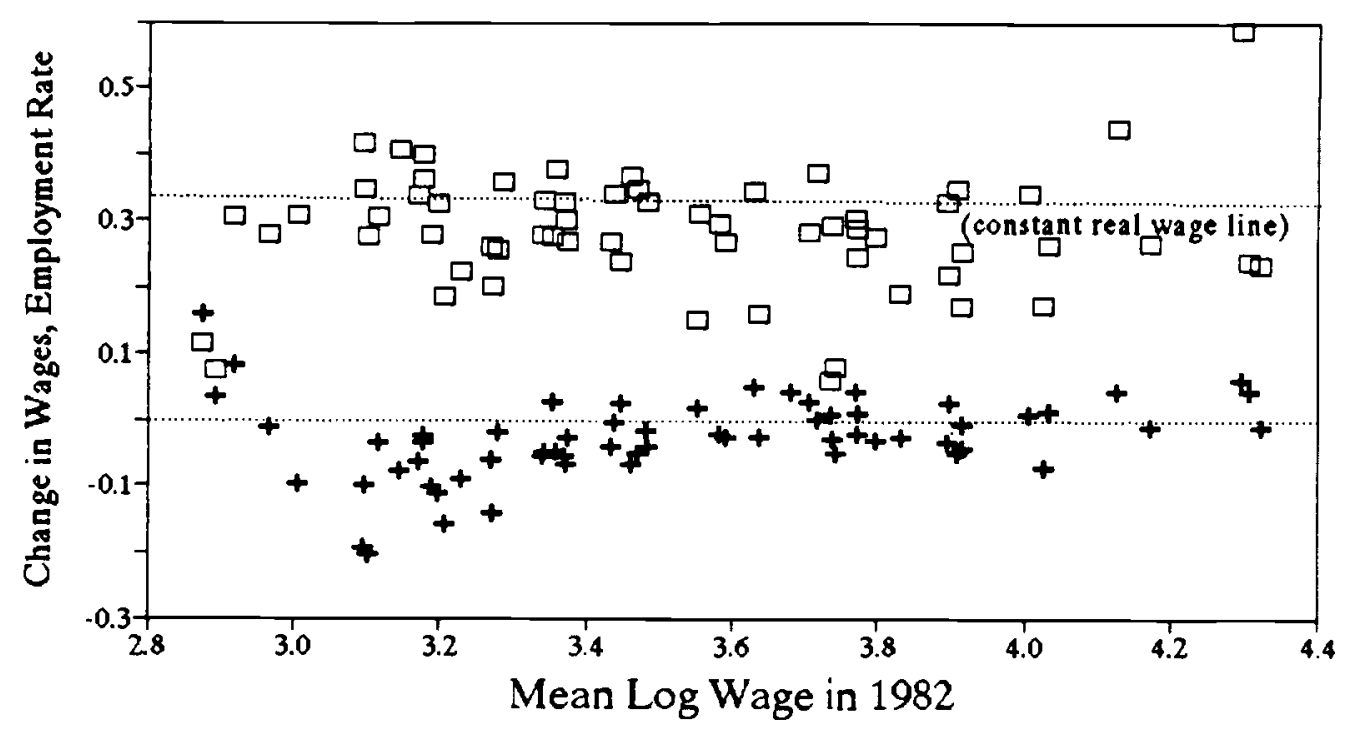

Mean Log Wage + Log Employment Rate

B. French Women, 1982-1989

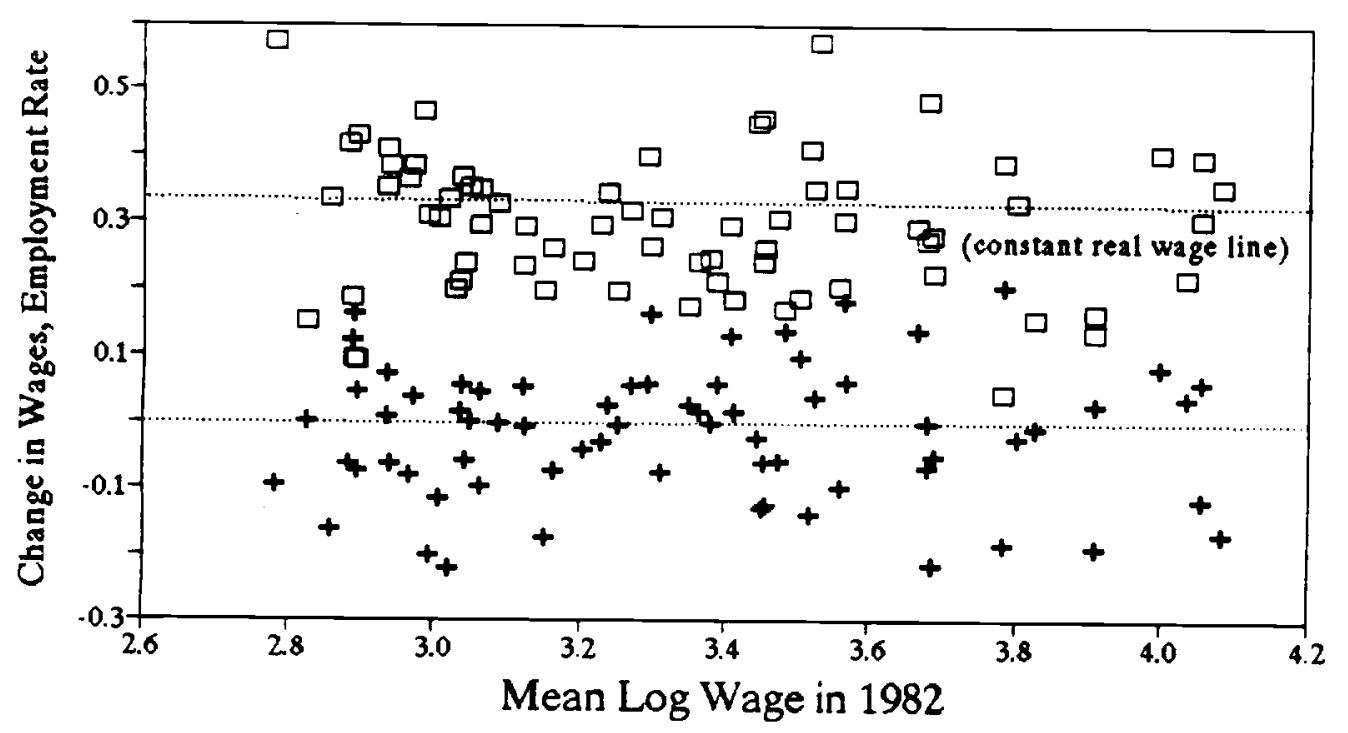

Mean Log Wage + Log Employment Rate 
Table 1: Utilization of Computers at work in U.S., Canada, and France

United states

1989

1. overall

2. By Gender:

Men

Ratio: Men/women

37.4

43.4

32.3

0.74 women

7.8

12.4

37.2

54.5

0.23

0.68

0.50

Ratio: High

School/College

58.

0.13

0.23
Canada France

1989

1991

34.0

37.6

31.2

0.83

14.6

40.2

0.73

Notes: U.S. data are from Krueger (1993). Canadian data are from Lowe (1991). French data are from unpublished tabulations of the 1991 Labor force survey. In all three countries, use of a computer includes word-processing, micro- and mainframe computing. aln france, this category includes those with no degree, and those whose highest qualification is a CEP (elementary school) certificate. bIn france, this category includes those whose highest qualification is either BEPC (roughly, junior high school) or CAP (vocational or technical school), or Baccalaureate (academic high school).

cIn U.S., this category includes those with 16 years of education. In canada, it includes those with a university degree. In france, it includes those with an Etudes superieur qualification. 
Table 2: Imports as a Fraction of GDP in U.S., canada, and France

A. United States

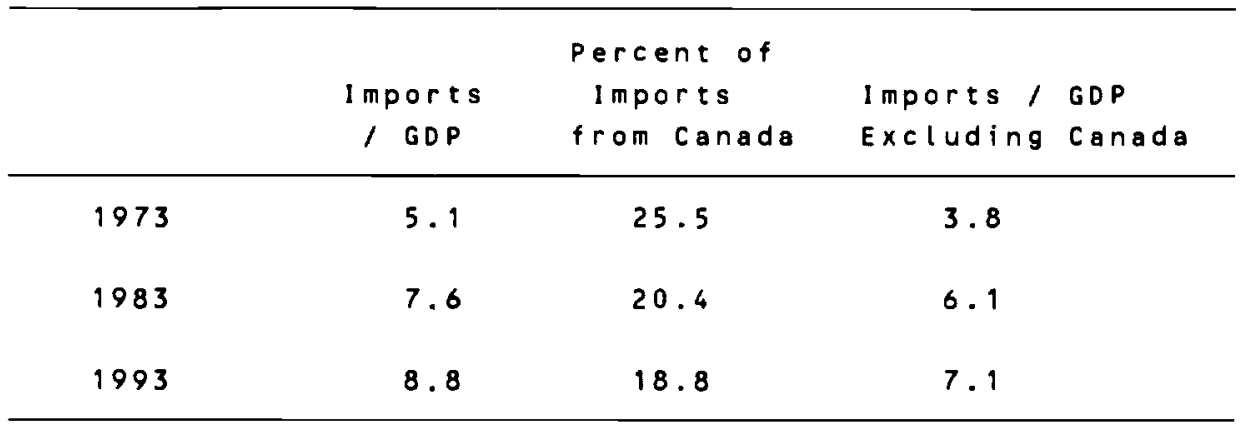

8. Canada

\begin{tabular}{|c|c|c|c|}
\hline & \multirow[b]{2}{*}{$1 \mathrm{mports}$} & \multicolumn{2}{|l|}{ Percent of } \\
\hline & & $1 \mathrm{mports}$ & Imports / GDP \\
\hline & $/$ GDP & from U.s. & Excluding U.S. \\
\hline 1973 & 17.8 & 70.7 & 5.2 \\
\hline 1983 & 18.0 & 72.1 & 5.0 \\
\hline 1993 & 24.1 & 73.2 & 6.5 \\
\hline
\end{tabular}

C. France

\begin{tabular}{|c|c|c|c|c|}
\hline & $\begin{array}{l}1 \text { mports } \\
/ \text { GDP }\end{array}$ & $\begin{array}{l}\text { Percent of } \\
\text { Imports } \\
\text { from Europe }\end{array}$ & $\begin{array}{l}\text { Imports } \\
\text { Excluding }\end{array}$ & $\begin{array}{l}\text { GDP } \\
\text { Europe }\end{array}$ \\
\hline 1973 & 14.7 & 67.8 & 4.8 & \\
\hline 1983 & 20.0 & 66.3 & 6.7 & \\
\hline 1993 & 24.1 & 73.2 & 6.5 & \\
\hline
\end{tabular}

Notes: U.S. data are taken from Economic Report of the President. (1994 ed) and statistical Abstract of the U.S. (1977 ed).

Canadian data are taken from Bank of Canada Review, (Autumn 1994 ed) and Canada Year Book (1980-81 ed).

French data are taken from Annuaire statistique de la france

( 1978 and 1990 eds) and Direction Generale des Duanes et Droits Indirect $(1994$ ed).

ancludes ECM, Sweden, Switzerland, Norway, Finland, USSR/Russia, and Eastern Europe. Entry for 1993 is based on 1989 data. 
Table 3: Changes in Relative supplies of Highly-Educated labor and Estimates of the Implied Wage Growth Attributable to changes in the

Distribution of the Population Across Age-Education Cells

\begin{tabular}{|c|c|c|c|c|c|}
\hline \multicolumn{3}{|c|}{ Men } & \multicolumn{3}{|c|}{ women } \\
\hline U.S. & Canada & France & U.S. & Canada & France \\
\hline
\end{tabular}

Changes in the fraction of highly

Educated Labor in the Population:

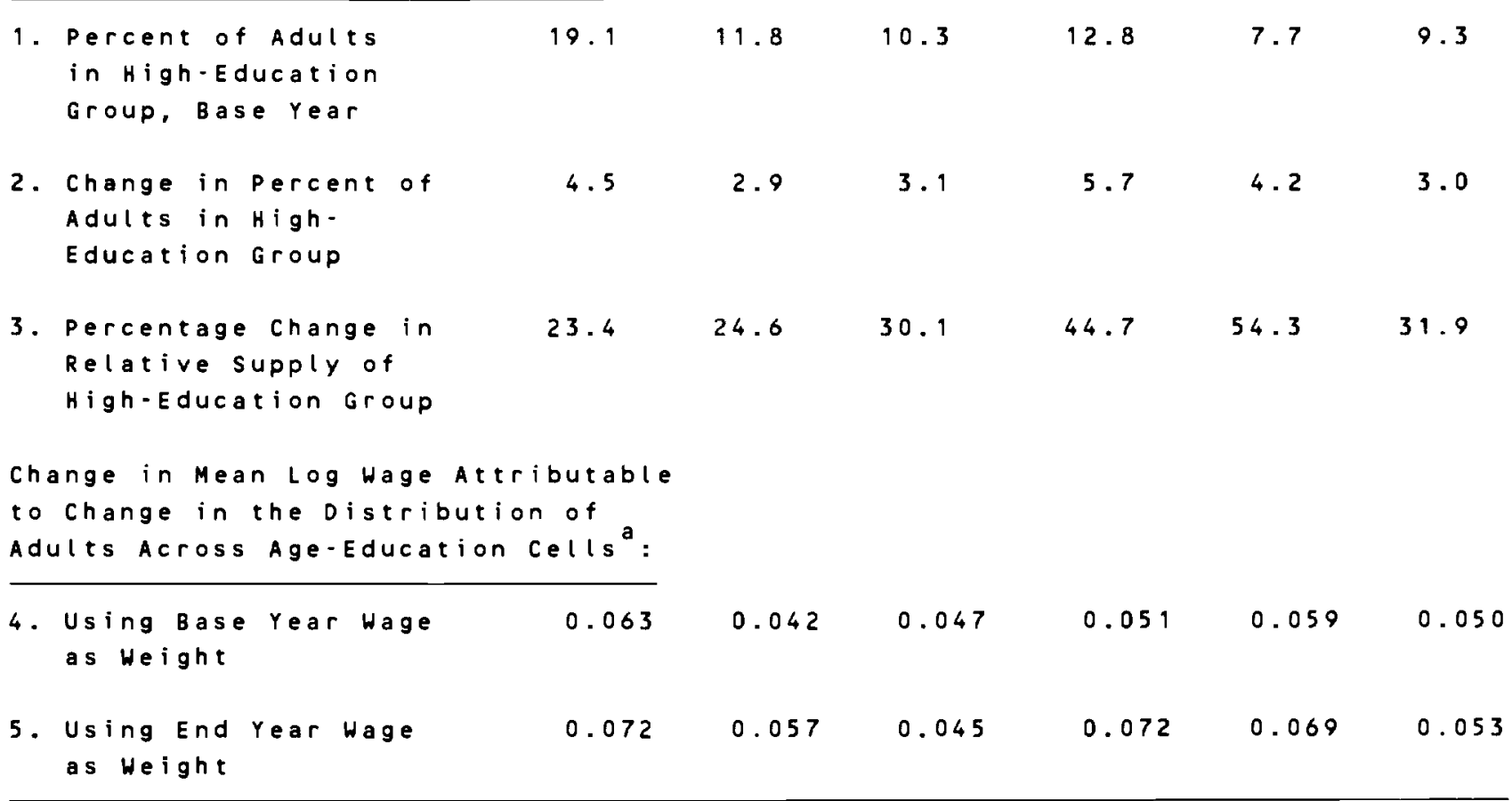

Notes: U.S. data includes whites only. Samples include individuals age 16.64

in the U.S., age 17-64 in Canada, and age 15-60 in France. Highly educated workers refer to those with 16 or more years of schooling in the U.S., those with a university degree in canada, and those who have completed Etudes Superior in France.

Entries represent a weighted average of the changes in the fraction of the adult population in different age-education cells between the base and end years, using as weights the mean log wage for workers in the cell in the base vear (row 4) or the mean log wage for workers in the cell in the end year (row 5). Analysis uses 225 age-education cells in U.s., 29 cells in Canada, and 70 cells in France. 
Table 4: Unionization Rates in United states, Canada, and France

\begin{tabular}{|c|c|c|c|c|}
\hline & \multirow{2}{*}{$\begin{array}{c}\text { United } \\
\text { States } \\
\text { (membership) }\end{array}$} & \multirow[b]{2}{*}{$\begin{array}{c}\text { Canada } \\
(m e m b e r s h i p)\end{array}$} & \multicolumn{2}{|c|}{ France } \\
\hline & & & Membership & Coverage \\
\hline 1970 & 29.6 & 33.6 & 23.1 & $-\cdot$ \\
\hline 1975 & $28.9 / 22.3$ & 35.6 & 22.9 & -- \\
\hline $1980 / 81$ & 22.7 & $36.7 / 34.2$ & $19.2 / 14.0$ & -- \\
\hline 1985 & 17.9 & 35.7 & 10.0 & - \\
\hline $1989 / 90$ & 16.3 & 33.1 & $-\cdot$ & 92.0 \\
\hline
\end{tabular}

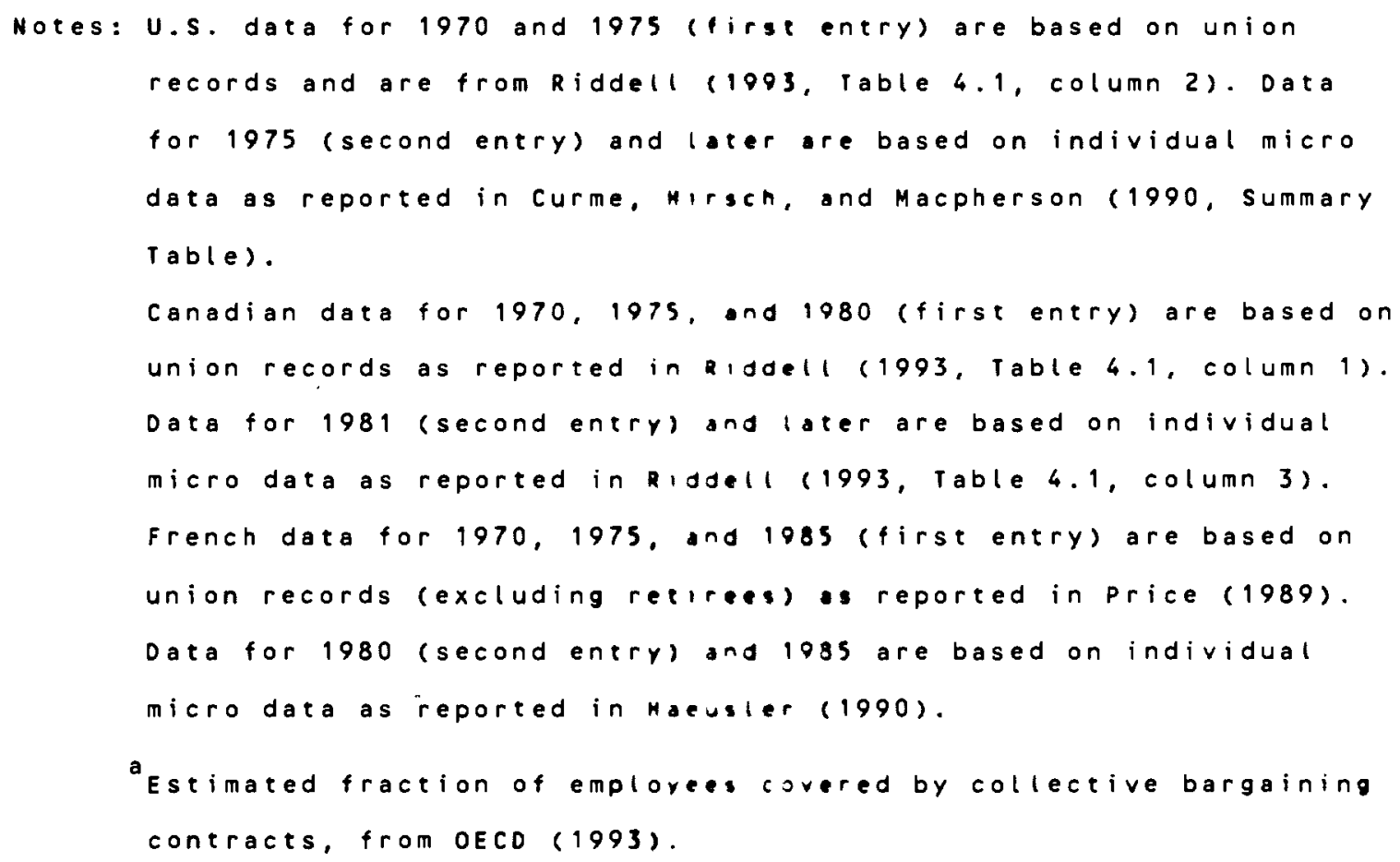


Table 5: Changes in the Level and Dispersion of Hourly Wages of Male and Female Workers in the United states, Canada, and France During the $1980 \mathrm{~s}$

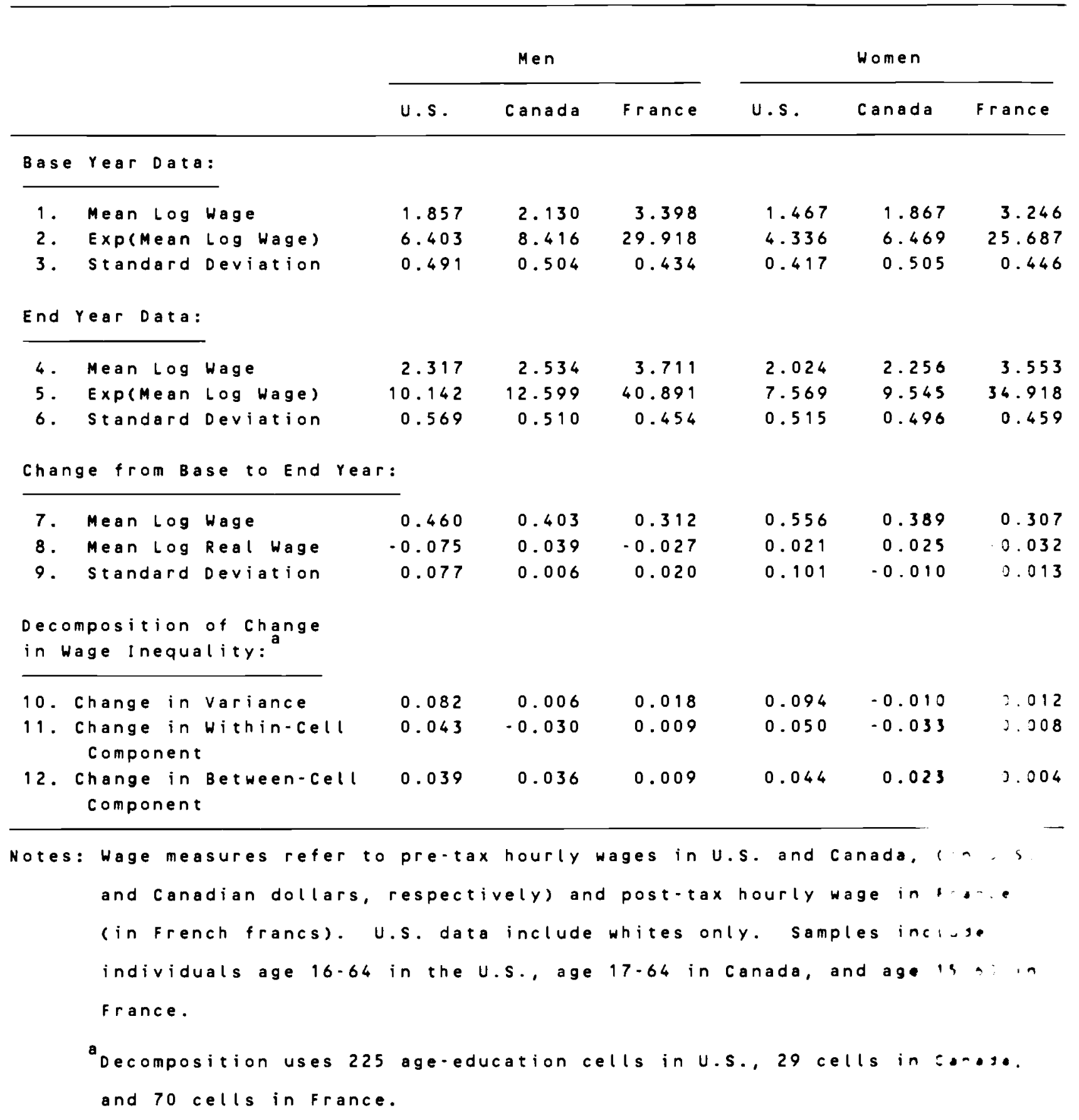


Table 6: Changes in Employment-population Rate of Males and Females in United states, Canada, and France Ouring the $1980 \mathrm{~s}$

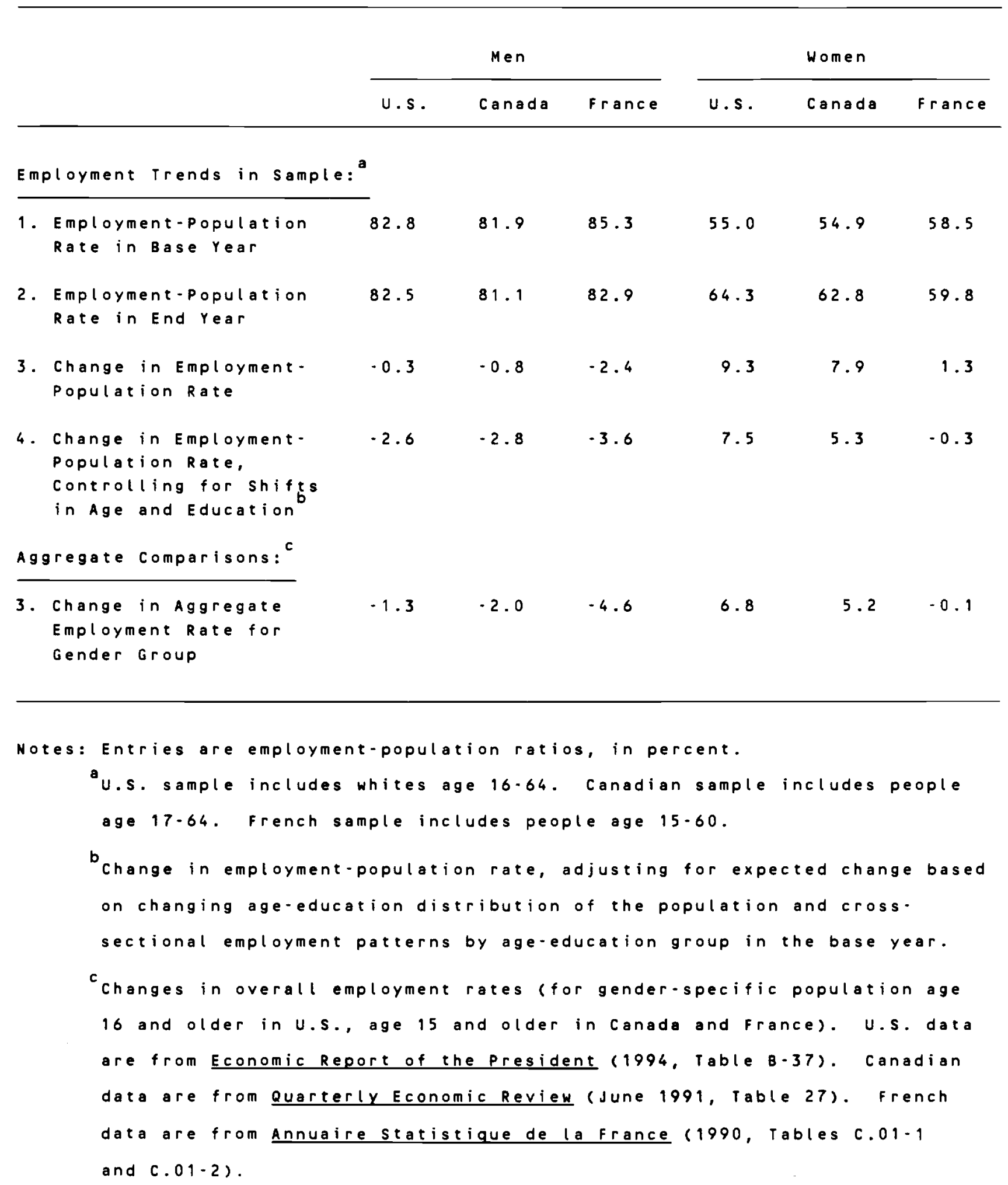


Table 7: Estimated Regression Models for Changes in Mean Cell Wages and Employment-Population Rates: United States, Canada, and France

\begin{tabular}{|c|c|c|c|c|c|c|}
\hline & \multicolumn{3}{|c|}{$\begin{array}{l}\text { Using Mean Cell Wage } \\
\text { in Base Year as } \\
\text { Demand Shift Index: }\end{array}$} & \multicolumn{3}{|c|}{$\begin{array}{l}\text { Using Average Computer } \\
\text { Use Rate in Late } 1980 \text { s } \\
\text { as Demand Shift Index: }\end{array}$} \\
\hline & $\begin{array}{l}\text { Mean L } \\
\text { Raw } \\
(1)\end{array}$ & $\begin{array}{c}\text { og Wage: } \\
\text { Adjusted } \\
\text { (2) }\end{array}$ & $\begin{array}{l}\text { Log Emp. } \\
\text { Rate } \\
\text { (3) }\end{array}$ & $\begin{array}{l}\text { Mean L } \\
\text { Raw } \\
(4)\end{array}$ & $\begin{array}{l}\text { Log Wage: } \\
\text { (5) justed } \\
\text { (5) }\end{array}$ & $\begin{array}{l}\text { Log Emp. } \\
\text { Rate } \\
(6)\end{array}$ \\
\hline \multicolumn{7}{|l|}{$\begin{array}{l}\text { Panel A: Men } \\
\text { United States 1979-89: }\end{array}$} \\
\hline 1. Demand Shift Index & $\begin{array}{c}0.17 \\
(0.02)\end{array}$ & $\begin{array}{c}0.19 \\
(0.02)\end{array}$ & $\begin{array}{l}0.04 \\
(0.02)\end{array}$ & $\begin{array}{l}0.31 \\
(0.03)\end{array}$ & $\begin{array}{c}0.41 \\
(0.02)\end{array}$ & $\begin{array}{c}0.13 \\
(0.02)\end{array}$ \\
\hline $\begin{array}{l}\text { 2. Change in Log } \\
\text { Population Share }\end{array}$ & $\begin{array}{l}-0.01 \\
(0.02)\end{array}$ & $\begin{array}{c}0.03 \\
(0.02)\end{array}$ & $\begin{array}{c}0.03 \\
(0.02)\end{array}$ & $\begin{array}{l}-0.01 \\
(0.02)\end{array}$ & $\begin{array}{c}0.01 \\
(0.01)\end{array}$ & $\begin{array}{c}0.01 \\
(0.02)\end{array}$ \\
\hline 3. R-squared & 0.34 & 0.41 & 0.08 & 0.46 & 0.68 & 0.16 \\
\hline \multicolumn{7}{|l|}{ Canada 1981-88: } \\
\hline 1. Demand Shift Index & $\begin{array}{c}0.26 \\
(0.10)\end{array}$ & $\begin{array}{c}0.09 \\
(0.06)\end{array}$ & $\begin{array}{l}-0.30 \\
(0.08)\end{array}$ & $\begin{array}{l}-0.14 \\
(0.12)\end{array}$ & $\begin{array}{l}-0.00 \\
(0.07)\end{array}$ & $\begin{array}{l}-0.04 \\
(0.03)\end{array}$ \\
\hline $\begin{array}{l}\text { 2. Change in Log } \\
\text { Population Share }\end{array}$ & $\begin{array}{c}0.06 \\
(0.08)\end{array}$ & $\begin{array}{c}0.13 \\
(0.05)\end{array}$ & $\begin{array}{c}0.16 \\
(0.07)\end{array}$ & $\begin{array}{c}0.26 \\
(0.08)\end{array}$ & $\begin{array}{l}0.18 \\
(0.04)\end{array}$ & $\begin{array}{c}0.05 \\
(0.09)\end{array}$ \\
\hline 3. R-squared & 0.43 & 0.55 & 0.34 & 0.31 & 0.51 & 0.01 \\
\hline \multicolumn{7}{|l|}{ France 1982-89: } \\
\hline 1. Demand Shift Index & $\begin{array}{c}0.01 \\
(0.04)\end{array}$ & $\begin{array}{l}-0.02 \\
(0.03)\end{array}$ & $\begin{array}{l}0.03 \\
(0.04)\end{array}$ & $\begin{array}{l}-0.11 \\
(0.06)\end{array}$ & $\begin{array}{l}-0.10 \\
(0.06)\end{array}$ & $\begin{array}{c}0.11 \\
(0.06)\end{array}$ \\
\hline $\begin{array}{l}\text { 2. Change in Log } \\
\text { Population share }\end{array}$ & $\begin{array}{l}-0.01 \\
(0.03)\end{array}$ & $\begin{array}{l}-0.00 \\
(0.03)\end{array}$ & $\begin{array}{l}0.05 \\
(0.03)\end{array}$ & $\begin{array}{c}0.01 \\
(0.03)\end{array}$ & $\begin{array}{c}0.01 \\
(0.03)\end{array}$ & $\begin{array}{l}0.04 \\
(0.03)\end{array}$ \\
\hline 3. R-squared & 0.00 & 0.01 & 0.08 & 0.04 & 0.04 & 0.12 \\
\hline \multirow{2}{*}{\multicolumn{7}{|c|}{$\begin{array}{l}\text { Panel B: Women } \\
\text { United States 1979-89: }\end{array}$}} \\
\hline & & & & & & \\
\hline 1. Demand Shift Index & $\begin{array}{c}0.30 \\
(0.03)\end{array}$ & $\begin{array}{c}0.38 \\
(0.03)\end{array}$ & $\begin{array}{c}0.12 \\
(0.04)\end{array}$ & $\begin{array}{c}0.18 \\
(0.03)\end{array}$ & $\begin{array}{c}0.38 \\
(0.03)\end{array}$ & $\begin{array}{c}0.13 \\
(0.04)\end{array}$ \\
\hline $\begin{array}{l}\text { 2. Change in Log } \\
\text { Population Share }\end{array}$ & $\begin{array}{c}0.07 \\
(0.02)\end{array}$ & $\begin{array}{c}0.12 \\
(0.02)\end{array}$ & $\begin{array}{c}0.07 \\
(0.03)\end{array}$ & $\begin{array}{l}0.14 \\
(0.02)\end{array}$ & $\begin{array}{c}0.15 \\
(0.02)\end{array}$ & $\begin{array}{c}0.08 \\
(0.02)\end{array}$ \\
\hline $\begin{array}{l}\text { 3. R-squared } \\
\text { Canada 1981-88: }\end{array}$ & 0.66 & \multicolumn{4}{|c|}{ Canada 1981-88: } & 0.20 \\
\hline 1. Demand Shift Index & $\begin{array}{l}0.14 \\
(0.09)\end{array}$ & $\begin{array}{l}0.17 \\
(0.09)\end{array}$ & $\begin{array}{l}-0.06 \\
(0.16)\end{array}$ & $\begin{array}{l}-0.08 \\
(0.11)\end{array}$ & $\begin{array}{l}0.13 \\
(0.10)\end{array}$ & $\begin{array}{l}0.23 \\
(0.17)\end{array}$ \\
\hline $\begin{array}{l}\text { 2. Change in Log } \\
\text { Population Share }\end{array}$ & $\begin{array}{c}0.02 \\
(0.06)\end{array}$ & $\begin{array}{l}0.05 \\
(0.06)\end{array}$ & $\begin{array}{l}0.09 \\
(0.10)\end{array}$ & $\begin{array}{c}0.13 \\
(0.06)\end{array}$ & $\begin{array}{c}0.09 \\
(0.05)\end{array}$ & $\begin{array}{l}-0.09 \\
(0.09)\end{array}$ \\
\hline 3. R-squared & 0.29 & 0.51 & 0.04 & 0.25 & 0.47 & 0.10 \\
\hline France 1982-89: & & & & & & \\
\hline 1. Demand Shift Index & $\begin{array}{l}-0.12 \\
(0.04)\end{array}$ & $\begin{array}{l}-0.14 \\
(0.03)\end{array}$ & $\begin{array}{l}.0 .04 \\
(0.05)\end{array}$ & $\begin{array}{l}-0.29 \\
(0.05)\end{array}$ & $\begin{array}{l}-0.29 \\
(0.04)\end{array}$ & $\begin{array}{l}-0.01 \\
(0.08)\end{array}$ \\
\hline $\begin{array}{l}\text { 2. Change in Log } \\
\text { Population Share }\end{array}$ & $\begin{array}{l}0.08 \\
(0.03)\end{array}$ & $\begin{array}{l}0.08 \\
(0.02)\end{array}$ & $\begin{array}{l}0.11 \\
(0.03)\end{array}$ & $\begin{array}{l}0.09 \\
(0.02)\end{array}$ & $\begin{array}{c}0.07 \\
(0.02)\end{array}$ & $\begin{array}{l}0.10 \\
(0.03)\end{array}$ \\
\hline 3. R-squared & 0.18 & 0.26 & 0.15 & 0.33 & 0.40 & 0.14 \\
\hline
\end{tabular}

Note: standard errors in parentheses. Notes continue on next page. 
Notes for Table 7 .

All models are estimated by weighted least squares on cell-level data. U.S. sample includes 225 age-education cells; Canadian sample includes 29 ageeducation cells; French sample includes 70 age-education cells. Cell weight is the fraction of the adult population in the cell in the base year. U.S. data includes only whites.

In columns 1 and 4 the dependent variable is the change in the mean cell wage between the base year and the end year. In columns 2 and 5 the dependent variable is the change in the mean cell wage, assuming that those who don't work would earn the minimum wage in the respective year. In columns 3 and 6 the dependent variable is the change in the log of the employment-population rate in the cell. 
Table 8: Estimated Models for Men and Women with Computer Use and Base Year Wage as Alternative Measures of Relative Demand Shocks.

\begin{tabular}{|c|c|c|c|}
\hline \multicolumn{2}{|c|}{$\begin{array}{c}\text { Using Mean Cell Wage } \\
\text { in Base Year as } \\
\text { Demand Shift Index: }\end{array}$} & \multicolumn{2}{|c|}{$\begin{array}{l}\text { Using Average Computer } \\
\text { Use Rate in Late } 1980 \text { s } \\
\text { as Demand Shift Index: }\end{array}$} \\
\hline Mean Log Wage: & Log Emp. & Mean Log Wage: & $\log E m$ \\
\hline $\begin{array}{l}\text { Raw } \text { Adjusted } \\
\text { (1) }\end{array}$ & $\begin{array}{l}\text { Rate } \\
\text { (3) }\end{array}$ & $\begin{array}{c}\text { Raw Adjusted } \\
\text { (4) }\end{array}$ & $\begin{array}{l}\text { Rate } \\
(6)\end{array}$ \\
\hline
\end{tabular}

United States 1979-89:

$\begin{array}{lcccccc}\text { 1. Al1 Men } & 0.17 & 0.20 & 0.06 & 0.30 & 0.41 & 0.14 \\ & (0.02) & (0.02) & (0.01) & (0.02) & (0.02) & (0.02) \\ \text { 2. Men Age } & 0.27 & 0.31 & 0.06 & 0.33 & 0.39 & 0.08 \\ \text { 25-54 Only } & (0.03) & (0.04) & (0.01) & (0.02) & (0.02) & (0.01) \\ & & & & & & 0.31 \\ \text { 3. A11 Women } & 0.37 & 0.50 & 0.19 & 0.52 & 0.21 \\ & (0.02) & (0.02) & (0.03) & (0.03) & (0.03) & (0.03)\end{array}$

Canada 1981-88:

$\begin{array}{lcccccc}\text { 1. All Men } & 0.31 & 0.20 & -0.16 & 0.11 & 0.17 & 0.05 \\ & (0.07) & (0.05) & (1) .06) & (0.11) & (0.07) & (0.09) \\ \text { 2. Men Age } & 0.22 & 0.28 & 011 & 0.07 & 0.13 & 0.08 \\ \text { 25-54 Only } & (0.13) & (0.12) & (0.0) & (0.10) & (0.09) & (0.03) \\ \text { 3. A11 Women } & 0.16 & 0.24 & 005 & 0.12 & 0.27 & 0.16 \\ & (0.05) & (0.05) & (0.08) & (0.07) & (0.06) & (0.10)\end{array}$

France 1982-89:

\begin{tabular}{|c|c|c|c|c|c|c|}
\hline 1. Al1 Men & $\begin{array}{c}0.00 \\
(0.03)\end{array}$ & $\begin{array}{l}-0.02 \\
(0.03)\end{array}$ & $\begin{array}{l}\text { (1) } 115 \\
\text { (1) } 1131\end{array}$ & $\begin{array}{l}-0.10 \\
(0.06)\end{array}$ & $\begin{array}{l}-0.09 \\
(0.05)\end{array}$ & $\begin{array}{c}0.15 \\
(0.06)\end{array}$ \\
\hline $\begin{array}{l}\text { 2. Men Age } \\
15-54 \text { Only }\end{array}$ & $\begin{array}{l}-0.07 \\
(0.03)\end{array}$ & $\begin{array}{l}-0.03 \\
(0.04)\end{array}$ & (1) 14 & $\begin{array}{l}-0.18 \\
(0.05)\end{array}$ & $\begin{array}{l}-0.10 \\
(0.06)\end{array}$ & $\begin{array}{c}0.12 \\
(0.02)\end{array}$ \\
\hline . A11 Women & $\begin{array}{l}-0.06 \\
(0.03)\end{array}$ & $\begin{array}{l}-0.08 \\
(0.03)\end{array}$ & $\begin{array}{l}011) \\
(0.06)\end{array}$ & $\begin{array}{l}-0.20 \\
(0.05)\end{array}$ & $\begin{array}{l}-0.22 \\
(0.04)\end{array}$ & $\begin{array}{l}0.09 \\
(0.07)\end{array}$ \\
\hline
\end{tabular}

Notes: Standard errors in parentheses. See note to Table 7. In column 1-3, the (sole) independent variable is the mean cell wage in the base year. In colums 4-6, the (sole) independent variable is the proportion of cell workers using computers at work at the end of the 1980 s (1989 in the United States ard Canada, 1991 in France). 
Table 9: Minimum Distance Estimates of the Structural Parameters.

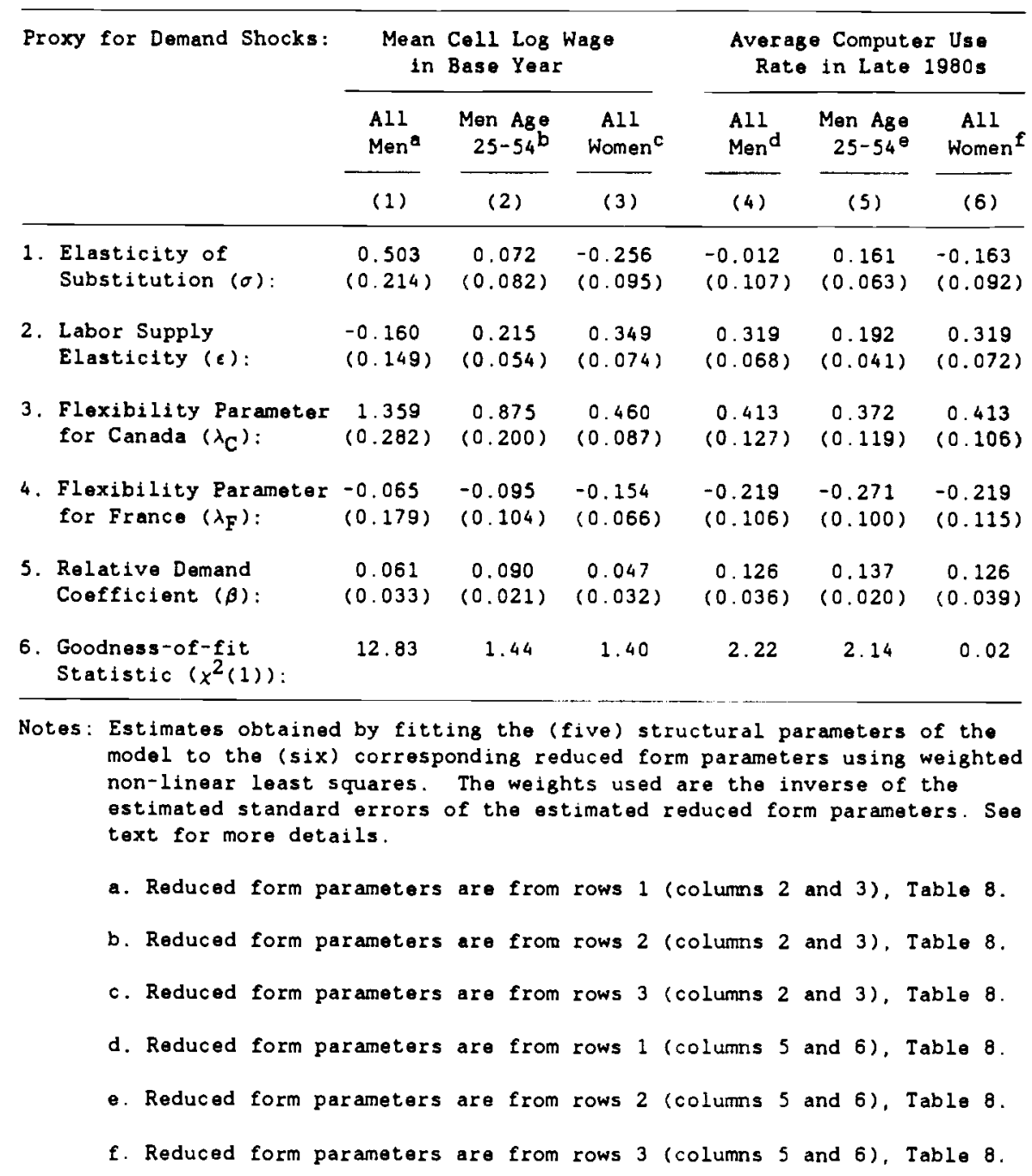

